\title{
Geochronology, geochemistry, and tectonic significance of the Shirenshan gneiss in the southern margin of the North China Block
}

\author{
Wang Jingya ${ }^{1}$, Ren Shenglian ${ }^{1 *}$, Dong Shuwen ${ }^{2}$, Li Longming ${ }^{1}$, Jiang Dazhi ${ }^{3}$, Shi Yonghong ${ }^{1}$, \\ Li Jiahao ${ }^{1}$, Song Chuanzhong ${ }^{1}$, Han Xu ${ }^{1}$, Li Zhenqiang ${ }^{1}$, and Ouyang Jue ${ }^{3}$
}

\footnotetext{
${ }^{1}$ HeFei University of Technology, School of Resources and Environmental Engineering, Hefei 230009, China; (migorhappyday@126.com; ren_lotus@126.com)

${ }^{2}$ Nanjing University, School of Geoscience and Engineering, Nanjing 230026, China

${ }^{3}$ Western University, London, School of Earth Sciences, Ontario N6A 3K7, Canada
}

doi: $10.4154 / g c .2019 .21$

Article history:

Manuscript received April 11, 2019

Revised manuscript accepted July 17, 2019

Available online December 20, 2019

Keywords: Qinling Orogenic Belt, North China Block, Shirenshan, Geochronology, Geochemistry, Petrology

\begin{abstract}
The Shirenshan Block is a complex geological body located in the southern margin of the North China Block (NCB). From south to north, it can be divided into the Taihua Group migmatite, and the Shirenshan gneiss and magmatic rocks. The petrographic features, tectonic setting, provenance, and geological age of the Shirenshan gneiss using comprehensive field investigations, microstructural analysis, zircon $\mathrm{U}-\mathrm{Pb}$ radioactive dating, and geochemical analyses were investigated for this study. The petrology, geochemistry, and geochronology of the Shirenshan gneiss suggests that it is mainly a felsic rock and its protolith was a high-K calc-alkaline series A-type granite. The protolith is high in $\mathrm{SiO}_{2}, \mathrm{Al}_{2} \mathrm{O}_{3}, \mathrm{~K}_{2} \mathrm{O}, \mathrm{Na}_{2} \mathrm{O}$, and low in $\mathrm{CaO}$ and $\mathrm{MgO}$. Overall, the $\mathrm{Sr}-\mathrm{Nd}$ isotope composition of the samples showed no significant difference, indicating that the Taihua Group migmatite and the Shirenshan gneiss have the same source material. The Shirenshan block may be partially melted from the Taihua group and formed during activity of the LuoLuan Fault. By the method of zircon dating analysis, the protolith age of the Shirenshan block was determined as $1559 \pm 16 \mathrm{Ma}$ (Early Proterozoic). Then, the crystallization age of the syntectonic migmatite is $439.2 \pm 7.6 \mathrm{Ma}$, which was formed by subduction of the Taihua Group. During the early Cretaceous (119.5 $\pm 1.3 \mathrm{Ma})$, the Shirenshan gneiss may have experienced regional migmatization and formed the zircon rims age of the Yanshanian period. Litho-geochemical features of the Shirenshan block are similar to A1-type granites indicating that they are post-orogenic. Therefore, the metamorphic deformation of the Shirenshan gneiss reflects the tectonics in the southern margin of the NCB
\end{abstract}

\section{INTRODUCTION}

Qinling orogenic belt is a complex subduction-collision orogenic belt that traverses China from east to west (XU et al., 1990, 2015 and Fig. 1). It was formed during several tectonic events and types of activities including subduction, collision, and the intracontinental orogeny of the Yangtze plate and the North China Block (PEI et al., 1995; ZHANG et al., 1997; SONG et al., 2002, 2006). The Qinling orogenic belt can be divided into several tectonic zones including the southern margin of the North China Block, the North Qinling, the South Qinling, and the northern margin of the Yangtze Block, based on its petrology and geotectonic features (ZHANG et al., 2001; DONG et al., 2003; WU et al., 2018). The North China Block has become one of the research hotspots in recent years due to its proximity to the North Qinling, complex, its composition, and multi-stage tectonic evolution.

The Shirenshan gneiss (the object of this paper), is located on the southern margin of the North China Block. It coincides with the northern margin of the North Qinling. Previous studies have shown (REN et al., 2013) that it is a product of subduction of the North Qinling beneath the North China Block. Therefore, an in-depth study of the structural geology, petrology, geochemistry, and geochronology of the Shirenshan gneiss is of great importance to further current understanding of the interactions between the North Qinling and the southern margin of the North
China Block. Therefore, on the basis of previous studies, comprehensive field petrology and structural geology investigations were undertaken, combined with geochemical and zircon $\mathrm{U}-\mathrm{Pb}$ chronology, to investigate the tectonic setting and to determine the absolute age of the Shirenshan gneiss. The results obtained from this research provide a foundation for further studies on the tectonic evolution of the Mesozoic intracontinental orogeny in the southern margin of the North China Block.

The focus of previous studies in this area was on the genesis and chronology of magmatic rocks. WANG et al. (1988) concluded that the Shirenshan gneiss was formed by remelting processes. They also proposed that the Shirenshan gneiss was an Stype granite formed by repeated metasomatism-remelting of the Kuanping group schist and gneiss. They suggested that evidence such as the gradual transition between the undeformed granite bodies and the surrounding gneiss, their complex mineralogy and chemical composition supports this idea. ZHANG et al. (1990) concluded that the Shirenshan gneiss is a mixed granitic gneiss, which is a progressive granite resulting from the effects of plate collision effect. LU et al. (1995) believed that the leftward horizontal sliding of the Luoluan fault zone was responsible for partial melting and the diapiric uprising of the Taihua group rocks. The partial melt was then intruded into the Taihua group in a "wedge-shape" and deformed together with the Luoluan fault zone to form the granitic gneiss - Shirenshan gneiss. Although there have been several research investigations reported on the 

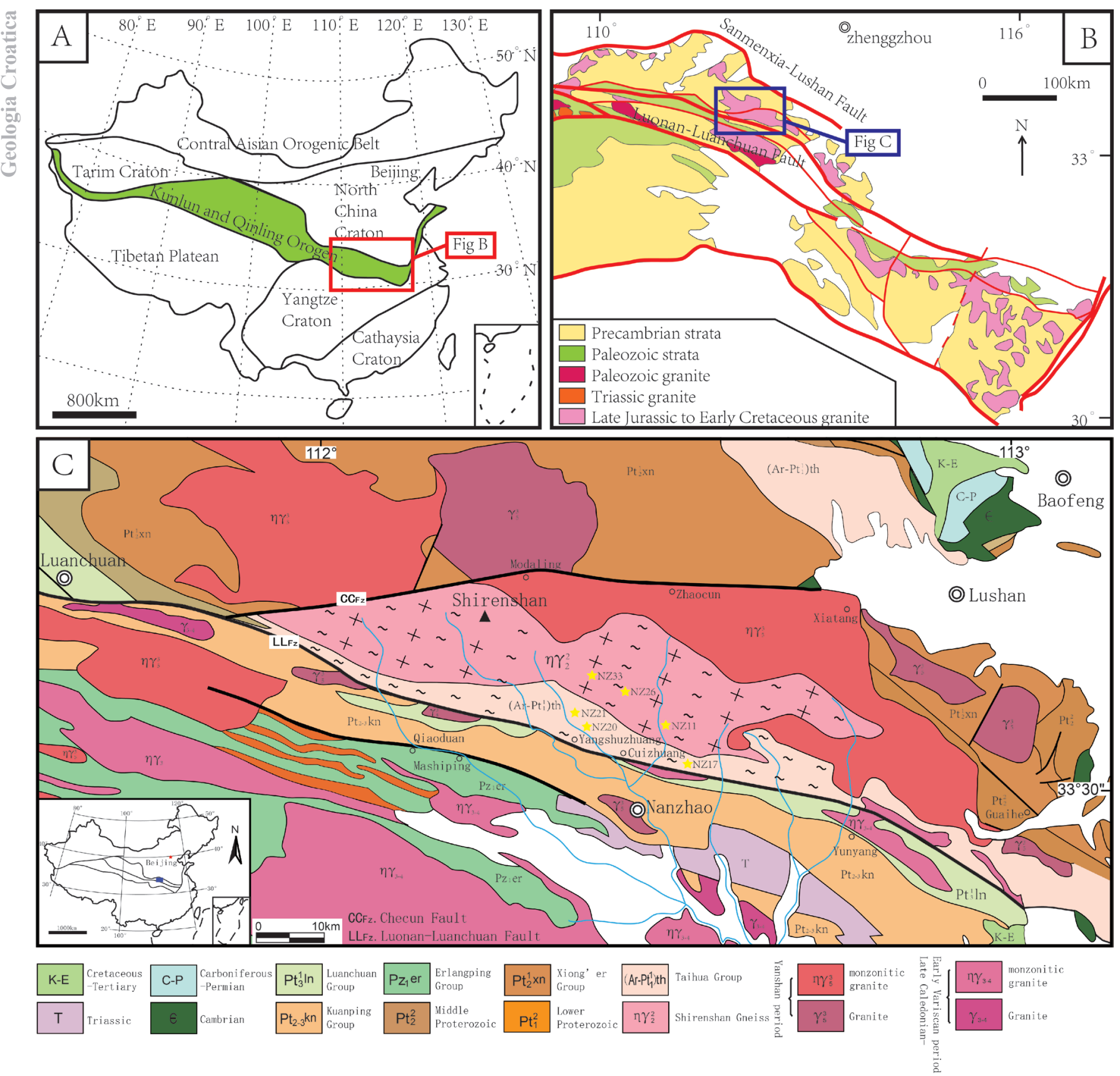

Figure 1. Geological map of the Shirenshan block, North Qinling (accroding to ZHANG et al., 1997).

petrology of the Shirenshan gneiss, there is still a lack of understanding of its deformation and tectonic evolution. Hence, the main objective of this research work is to address this issue.

\section{GEOLOGICAL SETTING}

The Shirenshan gneiss is located in Nanzhao County, Henan Province. It is a geological body with characteristic evidence of metamorphic deformation in the Shirenshan block of the Luanchuan-Fangcheng section (Fig. 1). The Shirenshan block has a surface exposure of about $2000 \mathrm{~km}^{2}$ and is structurally controlled by faults. To the north, the Checun fault separates the Shirenshan gneiss from the Xiong'er group volcanics. To the south, it is separated from the Kuanping group by the Luoluan fault zone.

The Shirenshan block consists of granite, Shirenshan gneiss and the Taihua group migmatite from north to south, respec- tively. Except for the northern granite, both the middle part of the Shirenshan gneiss and the southern Taihua group migmatite have experienced multiple episodes of strong deformation. They all show evidence of tectonic activities such as subduction, collision, and subsequent intracontinental orogeny in different periods.

\section{SAMPLING AND PETROGRAPHIC STUDIES}

In order to understand the deformation of the Shirenshan gneiss and the Taihua Group migmatite, samples from these two types were collected for petrographic studies.

The Shirenshan gneiss samples NZ11, sample NZ26, and NZ33 were collected from the middle of the Shirenshan block. They have a medium grain size, platy granitic structure, a gneissic structure, and a local banded and eye-shaped texture. The eyeball structure is composed of flattened and elongated 
gray-white plagioclase and light-coloured red plagioclase. The content varies greatly and exhibits obvious preferred orientation. Mylonitization can be commonly observed in the gneiss. The quartz is elongated, similar to a ribbon, and the feldspar is porphyroclastic. The shape of the feldspar has the characteristics of asymmetric organization, illustrating the left-lateral sliding shearing motion.
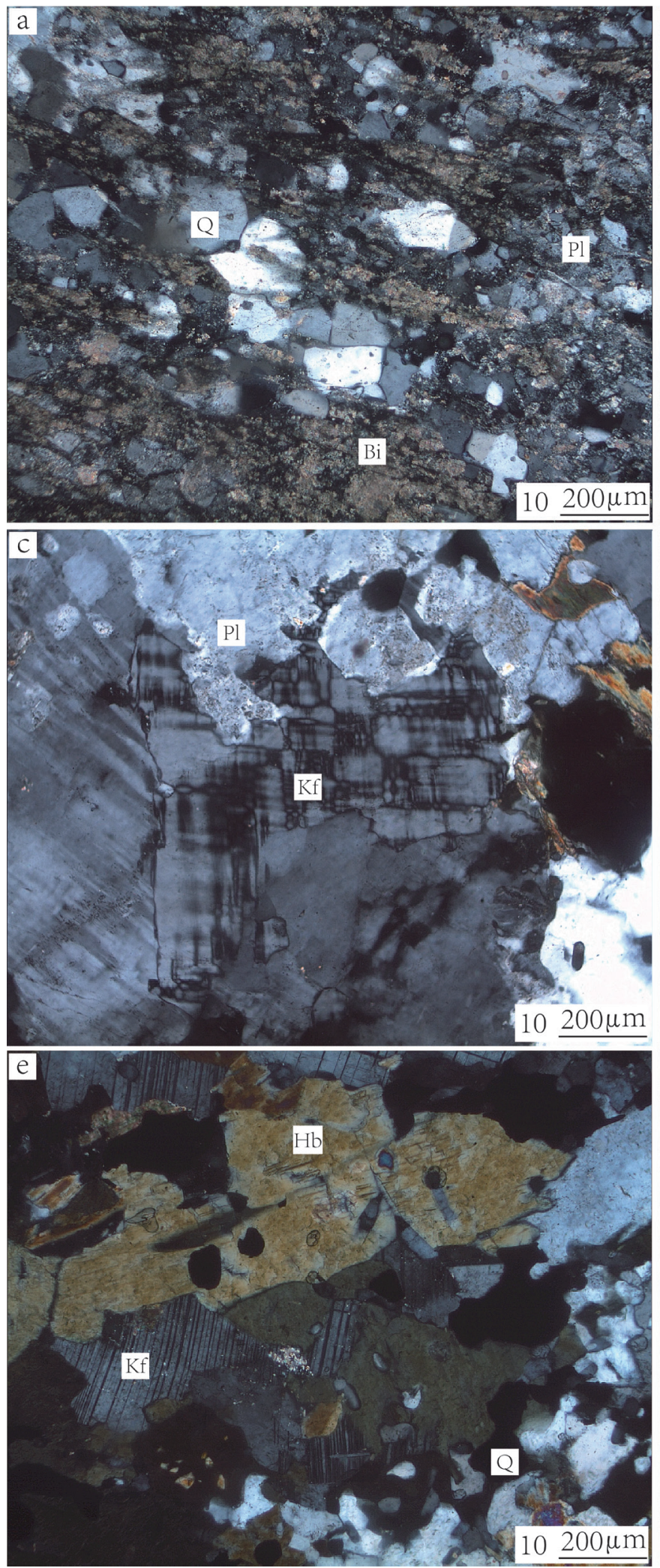

Sample NZ11 is a felsic gneiss collected from the NanzhaoCuhuang section (sampling position coordinates: N3336'21.06”, E112 23 ' $\left.13.8^{\prime \prime}\right)$. It is mainly composed of quartz (50-65 vol \%), feldspar (30-35 vol \%), mica (10-15 vol \%), and amphibole (<1vol $\%$ ) (Fig. 2a). Quartz is fine-grained in the form of striped singlegrains and granular aggregates showing preferred orientation which is an indication of the direction of tectonic movement. Pla-
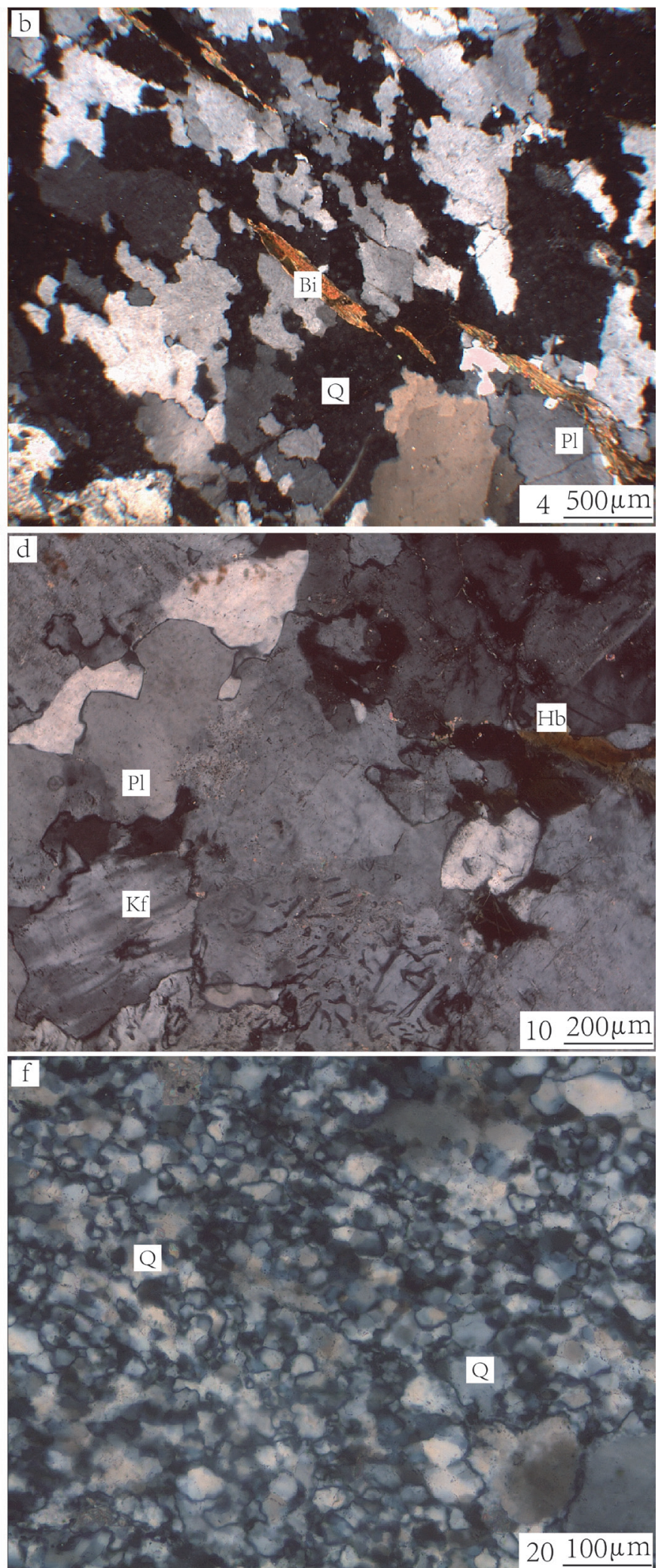

Figure 2. Microstructural features of the samples. (a) NZ-11; (b) NZ-26; (c) NZ-33; (d) NZ-17; (e) NZ-20; (f) NZ-21 
gioclase is fresh with polysynthetic twin development. Dark minerals are mainly composed of biotite, which are distributed as fine pieces. They are also sparsely distributed and show preferred orientation and gneissic structure.

Sample NZ26 is a biotite plagio-gneiss collected from Liang-

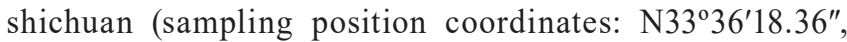
E112 $\left.{ }^{\circ} 19^{\prime} 48.18^{\prime \prime}\right)$. It is mainly composed of quartz (65-70 vol \%), feldspar (35-40 vol \%), mica (5-10 vol \%), and amphibole $(<1$ vol \%) (Fig. 2b). Part of the feldspar is sericitized and characterized by irregular grain boundaries, wavy and banded extinction, and preferred orientation. Dark minerals are mainly composed of biotite and a small amount of amphibole. The biotite shows a strongly preferred orientation.

Sample NZ33 is a biotite-bearing granitic gneiss, collected from Baichitan, Nanzhao County, Henan Province (sampling location coordinates: $\left.\mathrm{N} 33^{\circ} 39^{\prime} 24.66^{\prime \prime}, \mathrm{E} 112^{\circ} 17^{\prime} 19.44^{\prime \prime}\right)$. It is mainly composed of quartz (45-50 vol \%), feldspar (50-55 vol \%), mica $(10-15 \mathrm{vol} \%)$, and amphibole ( $<1$ vol \%) (Fig. 2c). Quartz particles are relatively uniform in size with curved grain boundaries. The feldspar particles are small, dominated by potassium feldspar, with lattice-like twin crystal development, some with sericitization. Dark minerals are mainly composed of amphibole and biotite with obvious preferred orientation and a gneissic structure.

The three rock samples from the Shirenshan gneiss are generally from the magmatic rock structure and the minerals did not undergo obvious dynamic recrystallization except for the obvious dynamic recrystallization phenomenon and the mylonite structure in a localised deformation strip. In addition, the dark minerals have obvious orientation, and the microscopic features also show that the dark minerals did not undergo dynamic recrystallization. This indicates that the dark minerals were oriented during the rock crystallization process and are associated with the same tectonic magmatic rock, and the gneiss-like texture is protogenetic.

The Taihua Group migmatite samples NZ17, NZ20, and NZ21 were taken from the Taihua Group located in the south of the Shirenshan region. These rocks show a mainly massive structure and are oriented in a northwest-southeast direction. The main rock types include banded migmatites and amphibolite-bearing gneiss, biotite plagiogneiss, and felsic granulite. Quartz grains are all finegrained, irregular, lenticular, strip-like shape and sub-particleboundary migration recrystallization. The feldspar is curved crystal faces, and at the side, forming a core mantle structure.

Sample NZ17 is a plagioclase amphibole-bearing gneiss, collected from the Cuizhuang-Cangfang section (sampling position coordinates: $\left.\mathrm{N} 33^{\circ} 35^{\prime} 9.42^{\prime \prime}, \mathrm{E} 112^{\circ} 22^{\prime} 30.06^{\prime \prime}\right)$. It is mainly composed of quartz (40-45 vol \%), feldspar (50-55 vol \%), mica $(<5$ vol \%), and amphibole (5-10 vol \%) (Fig. 2d). The quartz particles are small and are distributed around a feldspar due to sub-grain dynamic recrystallization. The feldspar crystals are fresh showing polysynthetic twin development and exhibiting plastic deformation characteristics and clear subgranularization. Some of the residual speckles have a core-mantle structure, which shows strong metamorphic deformation. The inner side has a creep deformation structure which is a representative of high temperature. The dark minerals are mainly composed of biotite and hornblende. The biotite is more idiomorphic than the hornblende indicating that it is crystallized later.

Sample NZ20 is a hornblende-bearing felsic gneiss collected from Yangshuzhuang Village, Nanzhao County, Henan Province (sampling location coordinates: N33 $35^{\prime} 17.16^{\prime \prime}$, E112 $\left.19^{\prime} 29.94^{\prime \prime}\right)$. It is mainly composed of quartz (40-45 vol \%), feldspar (35-40 vol \%), mica ( $<1$ vol \%), and amphibole (20-25 vol \%) (Fig. 2e). Quartz is strip-shaped, the grain boundary is curved into a leaf shape, and dynamic recrystallization is dominated by boundary migration with a sub-particle form. The feldspar residuals are large, in irregular eyeball shape, with strong wavy extinction, much deformation and cracks. Most of the feldspars are striped with deformation distortion. There are some albite rims around the grains along with some recrystallization at the edges of the granules. The dark mineral is mainly hornblende.

Sample NZ21 is a biotite hornblende-bearing gneiss, collected from Shimiao Bay in Nanzhao County, Henan Province (sampling location coordinates: $\left.\mathrm{N} 33^{\circ} 35^{\prime} 44.88^{\prime \prime}, \mathrm{E} 112^{\circ} 19^{\prime} 42.6^{\prime \prime}\right)$. It is mainly composed of quartz (30-35 vol \%), feldspar (60-65 vol \%), mica (5$10 \mathrm{vol} \%$ ), and amphibole (10-15 vol \%) (Fig. 2f). Quartz is with fine granules and signs of strong deformation. All of the minerals exhibit sub-particle-boundary migration recrystallization with strong wavy extinction. The feldspar is in rotating porphyritic form and the ridges are bulged and recrystallized. The biotite is strongly deformed and shows signs of bending and kinking.

In general, the three rock samples from the Taihua Group show strong dynamic recrystallization. This is an indication that they have experienced a certain intensity of tectonic stress after crystallization. From north of the Luoluan fault zone, the grain size of the rocks gradually changes from fine granular, long strips, with strong preferred orientation to coarse-grained and semi-orientated to the granite protolith. The quartz changes from elongate crystals to granular texture, and the recrystallization migrates from sub-particles to the high-temperature boundary. The feldspar gradually changes from fractured and stress textures to subgranulation, with a core-mantle structure and K-metasomatism. These characteristics indicate that under the impact of the Luoluan fault zone, the intensity of deformation inside the Shirenshan block gradually weakens from the south Taihua group to the central Shirenshan gneiss.

\section{ANALYTICAL METHODS}

\subsection{Zircon dating analysis}

The single mineral separation of zircon was completed by the Langfang Laboratory of the Hebei Provincial Geological Prospecting Bureau. After polishing, the optical and cathode fluorescence (CL) of the zircon was observed and the U-Th-Pb isotope analysis was carried out using LA-ICP-MS. The zircon U-Pb dating analysis was completed in the LA-ICPMS Clean Laboratory of the Hefei University of Technology. The laser ablation aperture was $24 \mu \mathrm{m}$, helium was used as the carrier gas, argon was used as the compensation gas to adjust the sensitivity, and the international standard 91500 was used as the external standard. The NISTSRM610 was selected as the external standard of element content. For every test, 5 samples were selected and tested twice according to standard 91500 . The off-line data processing (including selection of sample and blank signals, instrument sensitivity drift correction, element content and $\mathrm{U}-\mathrm{Th}-\mathrm{Pb}$ isotope ratio and age calculation) was performed using the ICPMSDateCal 9.0 software. Detailed instrument operating conditions and data processing methods can be found in the literature (LIU et al., 2010).

\subsection{Analysis of major and trace elements}

The whole-rock element analysis was carried out in the Australian Minerals Laboratory (Guangzhou) of the Aussie Analytical Testing Group. The main elements were tested by fluorescence spectrometer (XRF), from the Axios instrument produced by PANalytical in the Netherlands. The trace elements were ana- 
lyzed by ICP735-ES in the Australian Minerals Laboratory (Guangzhou) of the Aussie Analytical Testing Group. The multielement content of the rock sample was determined by inductively coupled plasma emission spectroscopy (ICP-AES) after tetracid digestion, and 33 elements were detected (for list of elements see table 2). The alkali fusion method was also adopted for rare earth element (REE) analysis. The rock sample was added to $\mathrm{LiBO}_{2}$ to be uniformly mixed, melted in a furnace above $1000^{\circ} \mathrm{C}$, and 31 elements were detected by inductively coupled plasma mass spectrometry (ICP-MS). The detection instrument used is the Perkin Elmer, USA Production of Elan 9000.

\subsection{Whole rock $\mathrm{Sr}-\mathrm{Nd}$ isotopic analysis}

The Sr-Nd isotope separation test of rock samples was completed on the MC-ICP-MS from the laboratory of Nanjing Polypeptide Detection Technology Co., Ltd. The Rb-Sr and Sm-Nd isotope separations of whole rock samples include the process of sample preparation, chemical separation, and testing. The rock powder was dried in an oven and then weighed. Similar to the method of treating samples by ICP-MS, the acid dissolution method was used for the dissolution of the sample. $\mathrm{Rb}-\mathrm{Sr}$ and $\mathrm{Sm}-\mathrm{Nd}$ isotope separation was carried out using the conventional cation exchange resin method. The type of resin used for $\mathrm{Rb}-\mathrm{Sr}$ separation is AGSOW-X8, and HDEHP resin was used for Sm-Nd separation. For detailed separation and test procedures, see LIU et al. (2004).

\section{RESULTS}

\subsection{Zircon U-Pb age}

The zircon crystals of the Shirenshan gneiss are generally 50$150 \mu \mathrm{m}$ in diameter in the form of elongated grains with an aspect ratio of 2:1 3:1 (Fig. 3). The CL image shows that all zircons have a core-mantle structure. The core is relatively wide, generally larger than $40 \mu \mathrm{m}$, with bright luminescence and an obvious magmatic crystallization zone. The rims are narrow, generally less than $10 \mu \mathrm{m}$, with very few around $25 \mu \mathrm{m}$, with weak luminescence and no obvious structure. The zircon rim and the mantle are rugged, bay-like, jagged, and some dark patches are needle-like or bay-like into the magma core and light core residual can be found in the dark patches which indicate that it is a heterogeneous metamorphic recrystallized structure. The zircon CL structure indicates that the core is part of the magmatic original zircon which was not affected by the metamorphism, and the rim is formed by the later metamorphism episode. The ${ }^{206} \mathrm{~Pb} /{ }^{238} \mathrm{U}$ age-weighted average of 11 analysis points from the zircon rims is $119.5 \pm 1.3 \mathrm{Ma}$ $\left(\mathrm{MSWD}=1.5\right.$ ) (Table 1 and Fig. 4a). The ${ }^{206} \mathrm{~Pb} /{ }^{238} \mathrm{U}$ age of 9 analysis points from the zircon mantle ranges from 424 to $461 \mathrm{Ma}$ with the weighted mean age of $439.2 \pm 7.6 \mathrm{Ma}(\mathrm{MSWD}=1.14)$ (Table 1 and Fig. 4b). In addition, the ${ }^{206} \mathrm{~Pb} /{ }^{238} \mathrm{U}$ age of 7 analysis points from the zircon cores is $1506 \mathrm{Ma} \sim 1592 \mathrm{Ma}$ with the weighted average age of $1559 \pm 16 \mathrm{Ma}$ (Table 1).

Table 1. Zircon U-Pb isotopic data for the samples.

\begin{tabular}{|c|c|c|c|c|c|c|c|c|c|}
\hline \multirow{2}{*}{ Spot No. } & \multicolumn{3}{|c|}{ Content (ppm) } & \multicolumn{3}{|c|}{ Isotopic ratios } & \multicolumn{3}{|c|}{ Isotopic ages (Ma) } \\
\hline & Th & $U$ & $\mathrm{~Pb}$ & ${ }^{207} \mathrm{~Pb} /{ }^{206} \mathrm{~Pb}$ & ${ }^{207} \mathrm{~Pb} /{ }^{235} \mathrm{U}$ & ${ }^{206} \mathrm{~Pb} /{ }^{238} \mathrm{U}$ & ${ }^{207} \mathrm{~Pb} /{ }^{206} \mathrm{~Pb}$ & ${ }^{207} \mathrm{~Pb} /{ }^{235} \mathrm{U}$ & ${ }^{206} \mathrm{~Pb} /{ }^{238} \mathrm{U}$ \\
\hline NZ-1 & 589 & 2030 & 42.96 & 0.0509 & 0.1291 & 0.0183 & 235 & 123 & 117 \\
\hline NZ-2 & 472 & 1985 & 42.76 & 0.0472 & 0.1208 & 0.0184 & 57.5 & 116 & 118 \\
\hline NZ-3 & 527 & 3965 & 81.86 & 0.0499 & 0.1282 & 0.0184 & 191 & 122 & 118 \\
\hline $\mathrm{NZ}-4$ & 549 & 2347 & 49.66 & 0.0490 & 0.1257 & 0.0185 & 146 & 120 & 118 \\
\hline NZ-5 & 604 & 1982 & 46.91 & 0.0495 & 0.1318 & 0.0186 & 172 & 126 & 119 \\
\hline NZ-6 & 379 & 2093 & 45.39 & 0.0507 & 0.1325 & 0.0187 & 228 & 126 & 120 \\
\hline NZ-7 & 650 & 2808 & 60.01 & 0.0513 & 0.1335 & 0.0188 & 254 & 127 & 120 \\
\hline NZ-8 & 154 & 1319 & 27.28 & 0.0463 & 0.1217 & 0.0190 & 16.8 & 117 & 121 \\
\hline NZ-9 & 553 & 2112 & 46.50 & 0.0506 & 0.1342 & 0.0191 & 220 & 128 & 122 \\
\hline NZ-10 & 363 & 1730 & 37.18 & 0.0499 & 0.1319 & 0.0191 & 191 & 126 & 122 \\
\hline NZ-12 & 204 & 364 & 122.4 & 0.1022 & 3.7389 & 0.2631 & 1665 & 1580 & 1506 \\
\hline NZ-13 & 182 & 366 & 124.9 & 0.0970 & 3.6212 & 0.2681 & 1569 & 1554 & 1531 \\
\hline NZ-14 & 464 & 691 & 270.3 & 0.0959 & 3.5843 & 0.2684 & 1546 & 1546 & 1532 \\
\hline NZ-15 & 181 & 537 & 219.7 & 0.0994 & 3.6717 & 0.2728 & 1613 & 1565 & 1555 \\
\hline NZ-16 & 271 & 580 & 197.2 & 0.0981 & 3.7342 & 0.2729 & 1589 & 1579 & 1556 \\
\hline NZ-17 & 150 & 204 & 74.9 & 0.0973 & 3.7539 & 0.2766 & 1574 & 1583 & 1574 \\
\hline NZ-18 & 360 & 505 & 188.4 & 0.0997 & 3.9078 & 0.2801 & 1618 & 1615 & 1592 \\
\hline NZ-19 & 60.9 & 678 & 420 & 0.0682 & 0.6413 & 0.0680 & 876 & 503 & 424 \\
\hline NZ-20 & 55.0 & 575 & 459 & 0.0544 & 0.5141 & 0.0680 & 387 & 421 & 424 \\
\hline$N Z-21$ & 29.8 & 229 & 243 & 0.0842 & 0.8079 & 0.0698 & 1298 & 601 & 435 \\
\hline NZ-22 & 17.8 & 137 & 181 & 0.0545 & 0.5242 & 0.0699 & 394 & 428 & 436 \\
\hline$N Z-24$ & 40.7 & 403 & 328 & 0.0549 & 0.5369 & 0.0710 & 409 & 436 & 442 \\
\hline $\mathrm{NZ}-25$ & 29.8 & 290 & 221 & 0.0715 & 0.7043 & 0.0719 & 972 & 541 & 447 \\
\hline NZ-26 & 22.4 & 106 & 242 & 0.0595 & 0.6009 & 0.0728 & 583 & 478 & 453 \\
\hline NZ-27 & 32.0 & 275 & 245 & 0.0727 & 0.7396 & 0.0741 & 1006 & 562 & 461 \\
\hline
\end{tabular}




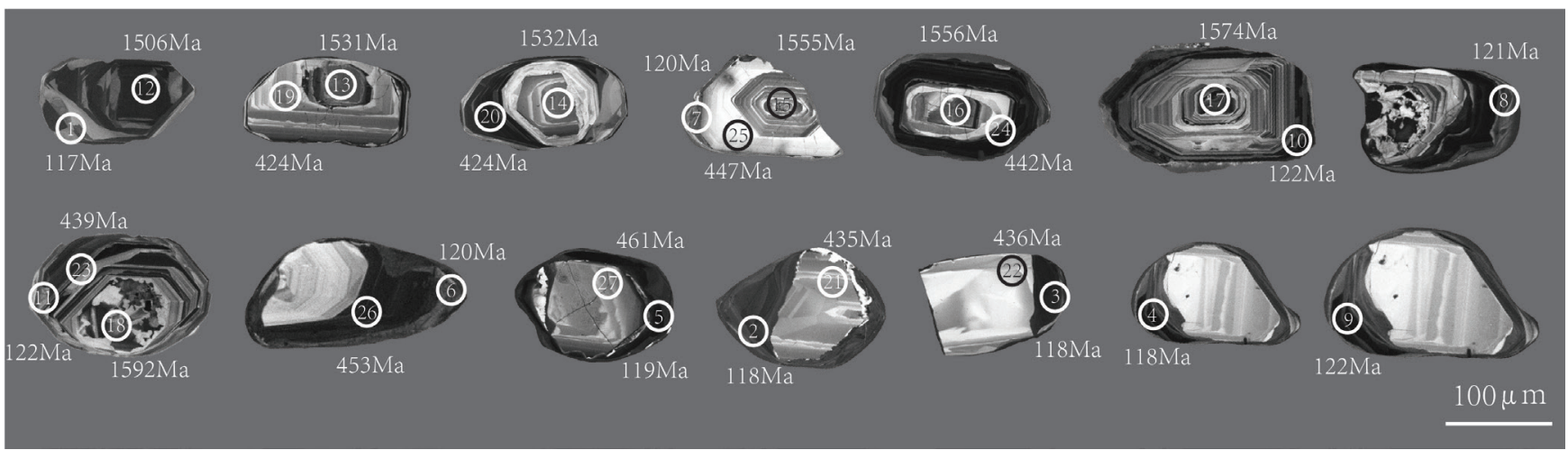

Figure 3. Representative cathodoluminescence $(\mathrm{CL})$ images for zircons from the sample, the open circles are spot analyses with available ${ }^{206} \mathrm{~Pb} / 238 \mathrm{U}$ ages.
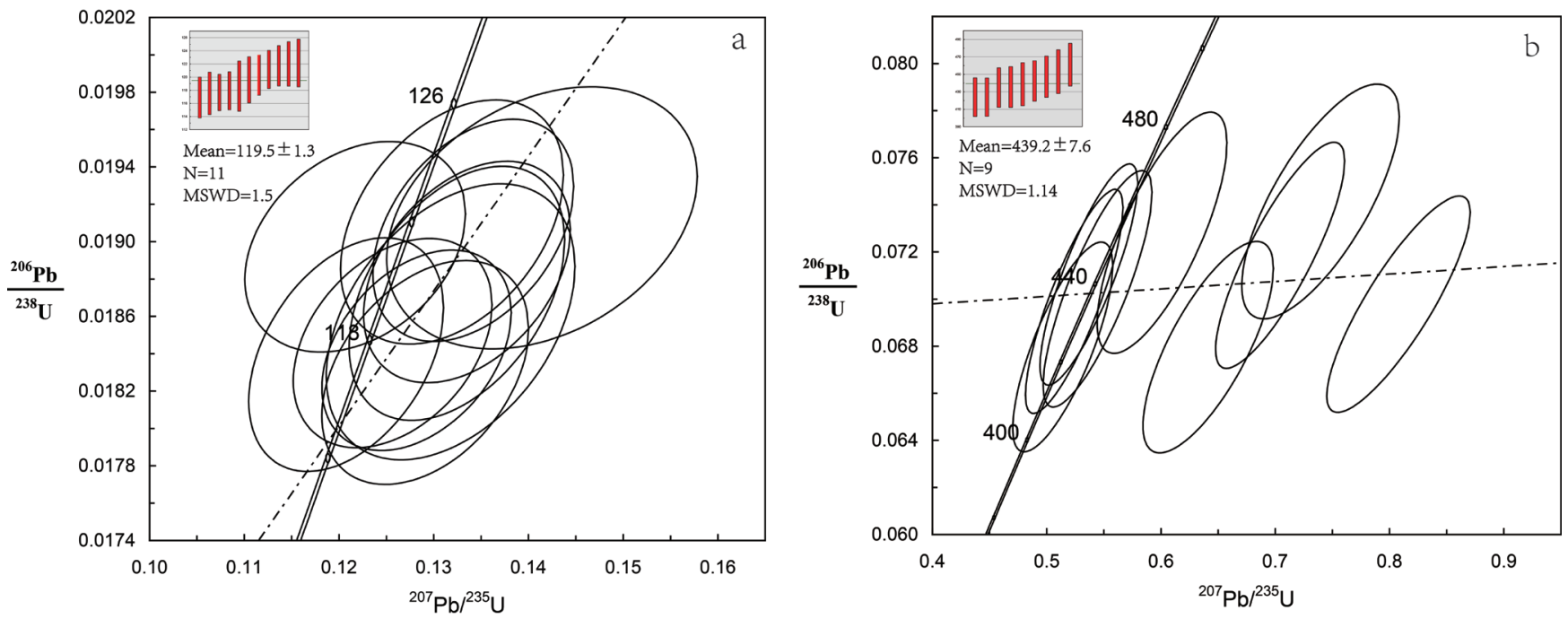

Figure 4. LA-ICP-MS zircon U-Pb isotopic dating. (a) U-Pb isotopic data from the zircon rims and (b) U-Pb isotopic data from the zircon mantles.

\subsection{Major elements}

A geochemical study of the samples was carried out to shed some light on the provenance of the Shirenshan gneiss and the Taihua Group (Table 2). The Shirenshan gneiss and Taihua Group migmatites are rich in silica $\mathrm{SiO}_{2}$ is 69.11-75.43wt\%, aluminum $\mathrm{Al}_{2} \mathrm{O}_{3}$ is $13.41-17.81 \mathrm{wt} \%$, and potassium $\mathrm{K}_{2} \mathrm{O}$ is $4.05-5.29 \mathrm{wt} \%$, with an aluminum saturation index (A/CNK) of 1.37-1.58; which belongs to the high-K calc-alkaline series of strong aluminous granite (Figs. 5, 6). In the Harker diagram (Fig. 7), the contents of $\mathrm{TiO}_{2}$,

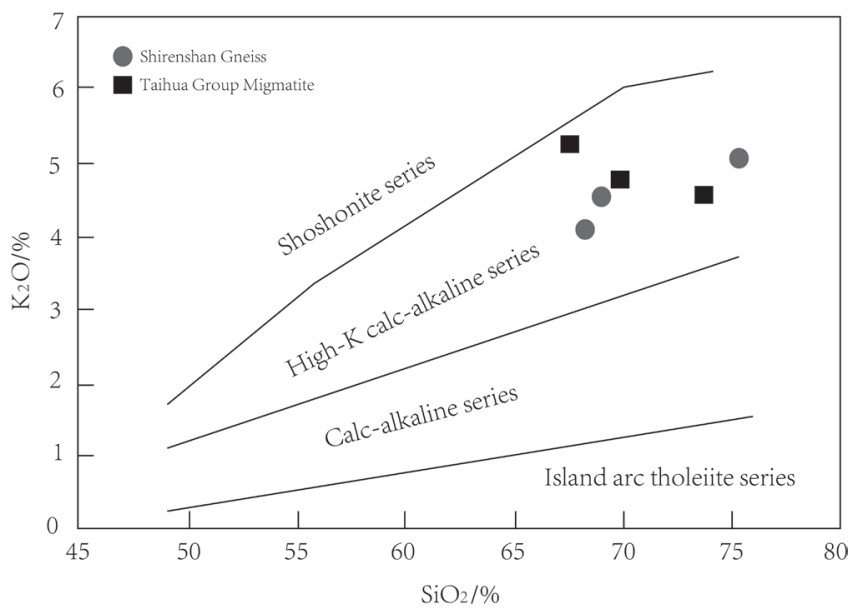

Figure 5. $\mathrm{SiO}_{2}-\mathrm{K}_{2} \mathrm{O}$ diagram for the samples (PECCERILLO et al., 1976).
$\mathrm{Al}_{2} \mathrm{O}_{3}, \mathrm{MgO}, \mathrm{CaO}, \mathrm{TFe}_{2} \mathrm{O}_{3}, \mathrm{Na}_{2} \mathrm{O}$, and $\mathrm{P}_{2} \mathrm{O}_{5}$ decrease with increasing $\mathrm{SiO}_{2}$ content showing a good negative linear correlation and indicating that fractional crystallization of sideromelane, plagioclase, and apatite may have played an important role in the process of magma evolution.

The rock is rich in iron and poor in magnesium. The mass fraction of $\mathrm{TFe}_{2} \mathrm{O}_{3}$ is $1.46-5.24 \mathrm{wt} \%$ and the mass fraction of $\mathrm{MgO}$ is $0.20-1.86 \mathrm{wt} \%$. The ratio of $\mathrm{TFeO} / \mathrm{MgO}$ is $2.54-13.39$ (average $6.08 \mathrm{wt} \%$ ); which is within the range of variation $\mathrm{TFeO} / \mathrm{MgO}$ in

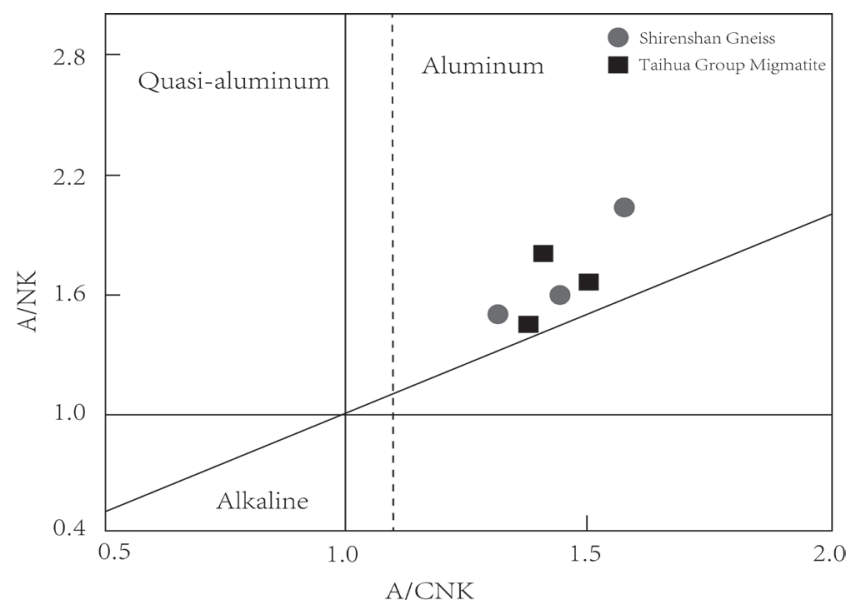

Figure 6. A/CNK-A/NK diagram for the samples (MANIAR et al., 1989). 


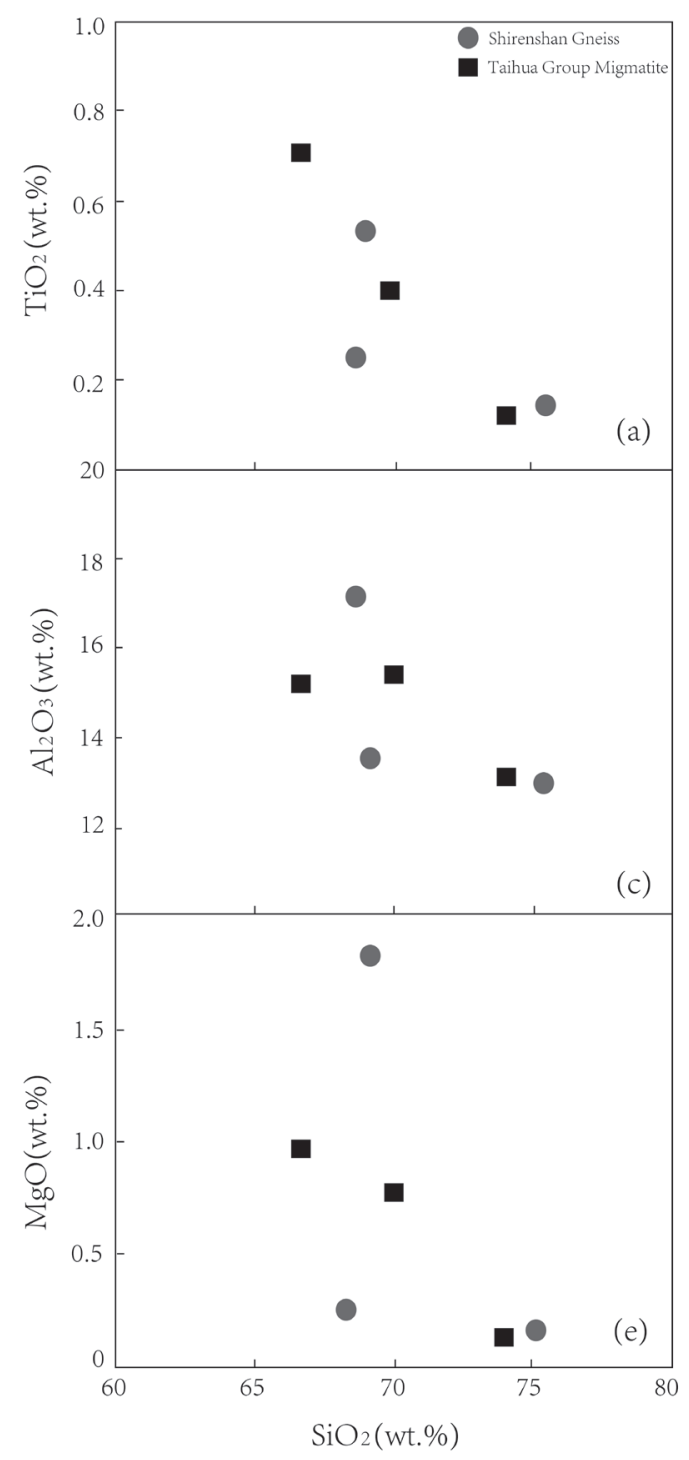

Figure 7. Harker variation diagrams for the samples.

type A granite (KING et al., 1997), and higher than the general I type (the average is 2.27 ) granite, the $\mathrm{S}$ type granite (the average is 2.38) and the M type granite (average 2.37) (King et al., 1997).

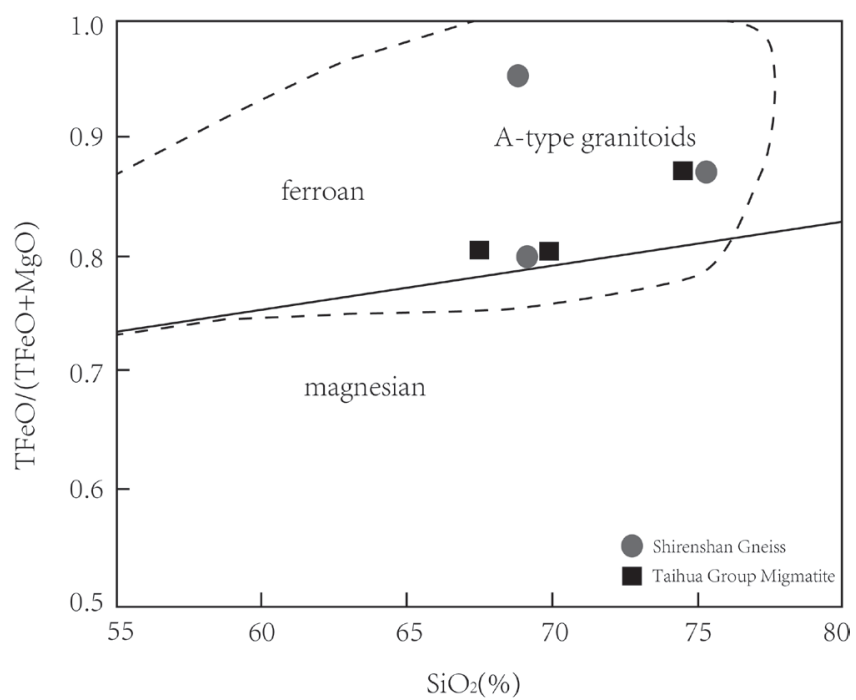

Figure 8. $w(\mathrm{TFeO}) /(\mathrm{TFeO}+\mathrm{MgO})-\mathrm{w}\left(\mathrm{SiO}_{2}\right)$ diagram for the samples (FROST et al., 2001).

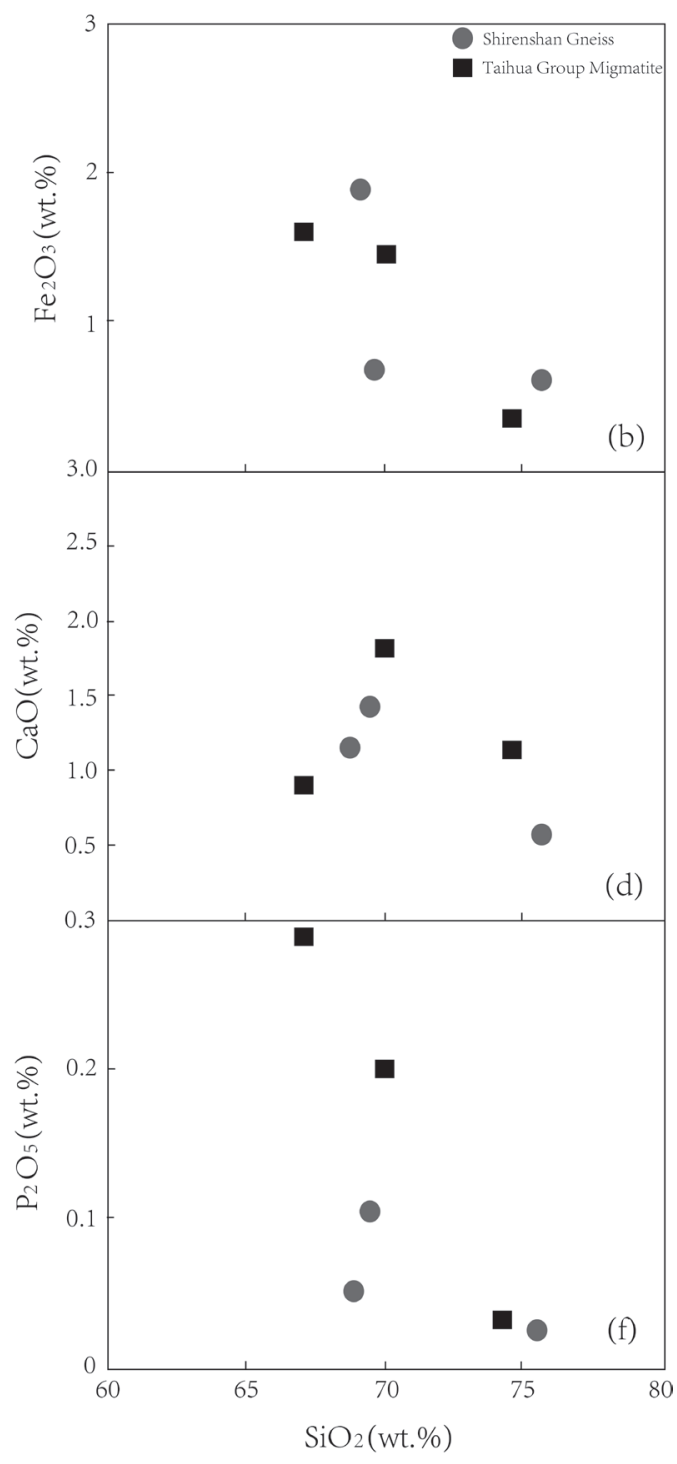

In the $\mathrm{w}(\mathrm{TFeO}) /(\mathrm{TFeO}+\mathrm{MgO})-\mathrm{w}\left(\mathrm{SiO}_{2}\right)$ diagram (Fig. 8), all of the samples fall into the iron region and also the area of A-type granite. From the characteristics of the main elements of the sample, there is no obvious difference between the Shirenshan gneiss and the Taihua Group migmatite which indicates that the original rocks of the Shirenshan gneiss may come from the Taihua Group.

\subsection{Trace and rare earth elements}

The total rare earth element ( $\mathrm{REE}$ ) content of the Shirenshan gneiss and Taihua group migmatite samples is between $84 \mathrm{ppm}-$ $230 \mathrm{ppm}$ and the content of light rare earth elements is $73 \mathrm{ppm}-$ $219 \mathrm{ppm}$. The heavy rare earth elements range between 10ppm$25 \mathrm{ppm}$ and the ratio of LREE/HREE is 6.41-20.07. Fig. 9a shows the chondrite-normalized rare earth element distribution and the rock generally indicates LREE enrichment, relative to HREE which are depleted.

The ratio of $(\mathrm{La} / \mathrm{Yb})_{\mathrm{N}}$ in the Shirenshan gneiss sample is 4.85-10.23 indicating that the light and heavy rare earth elements are highly fractionated. The $\delta \mathrm{Eu}$ is also between 0.28 and 0.85 with an average of 0.56 showing a generally V-shaped rare earth element distribution mode with moderate Eu negative anomaly. The mean value of $\delta \mathrm{Ce}$ is 0.97 and there is basically no Ce anomaly. The $(\mathrm{La} / \mathrm{Yb})_{\mathrm{N}}$ ratio of the Taihua Group is 35.08-63.42 indi- 
Table 2. Main and trace elements geochemical test results for the samples (main elements: wt\%; rare earth and trace elements: ppm).

\begin{tabular}{|c|c|c|c|c|c|c|}
\hline Sample & NZ11 & NZ26 & NZ33 & NZ17 & NZ20 & NZ21 \\
\hline $\mathrm{SiO}_{2}$ & 69.14 & 69.11 & 75.43 & 67.64 & 69.36 & 74.72 \\
\hline $\mathrm{TiO}_{2}$ & 0.57 & 0.22 & 0.13 & 0.78 & 0.41 & 0.12 \\
\hline $\mathrm{Al}_{2} \mathrm{O}_{3}$ & 13.60 & 17.81 & 13.41 & 15.18 & 14.94 & 13.45 \\
\hline $\mathrm{TFe}_{2} \mathrm{O}_{3}$ (Total of $\mathrm{Fe}_{2} \mathrm{O}_{3}$ ) & 5.24 & 4.17 & 1.65 & 3.83 & 2.83 & 1.46 \\
\hline TFeO (Total of FeO) & 4.72 & 3.75 & 1.48 & 3.45 & 2.55 & 1.31 \\
\hline $\mathrm{MnO}$ & 0.09 & 0.13 & 0.05 & 0.09 & 0.04 & 0.04 \\
\hline $\mathrm{MgO}$ & 1.86 & 0.28 & 0.22 & 0.93 & 0.72 & 0.20 \\
\hline $\mathrm{CaO}$ & 1.48 & 1.07 & 0.56 & 0.82 & 1.76 & 1.03 \\
\hline $\mathrm{Na}_{2} \mathrm{O}$ & 3.09 & 7.08 & 3.70 & 4.02 & 3.87 & 4.06 \\
\hline $\mathrm{K}_{2} \mathrm{O}$ & 4.05 & 4.84 & 4.98 & 5.29 & 4.87 & 4.52 \\
\hline $\mathrm{P}_{2} \mathrm{O}_{5}$ & 0.11 & 0.05 & 0.02 & 0.28 & 0.20 & 0.03 \\
\hline LOI & 0.51 & 0.30 & 0.36 & 1.03 & 0.64 & 0.67 \\
\hline $\mathrm{A} / \mathrm{CNK}$ & 1.58 & 1.37 & 1.45 & 1.50 & 1.42 & 1.40 \\
\hline $\mathrm{TFeO} / \mathrm{MgO}$ & 2.54 & 13.39 & 6.73 & 3.71 & 3.54 & 6.55 \\
\hline $\mathrm{Na}_{2} \mathrm{O} / \mathrm{K}_{2} \mathrm{O}$ & 0.76 & 1.46 & 0.74 & 0.76 & 0.79 & 0.90 \\
\hline $\mathrm{Ba}$ & 590 & 580 & 440 & 780 & 2060 & 600 \\
\hline $\mathrm{Cr}$ & 62 & 6 & 15 & 10 & 9 & 13 \\
\hline $\mathrm{Hf}$ & 6.2 & 15.8 & 4.8 & 4.9 & 6.2 & 4.0 \\
\hline $\mathrm{Nb}$ & 20.7 & 65.7 & 39.2 & 25.6 & 20.1 & 27.9 \\
\hline $\mathrm{Ga}$ & 18.9 & 21.1 & 19.0 & 20.5 & 20.7 & 19.4 \\
\hline $\mathrm{Rb}$ & 210 & 122.0 & 280 & 120.5 & 127.0 & 191.5 \\
\hline $\mathrm{Sr}$ & 187.0 & 193.5 & 120.0 & 240 & 850 & 175.0 \\
\hline $\mathrm{Ta}$ & 1.7 & 2.5 & 5.3 & 1.9 & 2.3 & 2.2 \\
\hline Th & 0.88 & 0.47 & 0.97 & 0.82 & 0.57 & 0.45 \\
\hline $\mathrm{U}$ & 5.18 & 0.71 & 14.85 & 2.00 & 4.39 & 5.41 \\
\hline La & 44.8 & 16.2 & 40.8 & 40.1 & 50.4 & 28.9 \\
\hline $\mathrm{Ce}$ & 83.8 & 39.2 & 75.7 & 84.2 & 107.0 & 53.7 \\
\hline $\operatorname{Pr}$ & 8.97 & 4.90 & 7.91 & 9.61 & 11.50 & 5.19 \\
\hline $\mathrm{Nd}$ & 34.1 & 20.0 & 27.9 & 37.8 & 42.1 & 17.2 \\
\hline $\mathrm{Sm}$ & 6.37 & 3.77 & 5.30 & 6.36 & 6.88 & 3.01 \\
\hline $\mathrm{Eu}$ & 3.15 & 1.64 & 4.29 & 2.25 & 1.30 & 2.11 \\
\hline $\mathrm{Gd}$ & 5.80 & 3.18 & 5.46 & 5.80 & 4.61 & 2.77 \\
\hline $\mathrm{Tb}$ & 0.88 & 0.47 & 0.97 & 0.82 & 0.57 & 0.45 \\
\hline Dy & 5.40 & 2.78 & 6.48 & 4.66 & 3.02 & 3.14 \\
\hline Ho & 1.05 & 0.54 & 1.31 & 0.87 & 0.51 & 0.66 \\
\hline $\mathrm{Er}$ & 3.15 & 1.64 & 4.29 & 2.25 & 1.30 & 2.11 \\
\hline $\mathrm{Tm}$ & 0.48 & 0.28 & 0.71 & 0.32 & 0.18 & 0.35 \\
\hline $\mathrm{Yb}$ & 3.12 & 1.85 & 4.72 & 1.92 & 1.18 & 2.46 \\
\hline $\mathrm{Lu}$ & 0.51 & 0.33 & 0.80 & 0.29 & 0.17 & 0.40 \\
\hline $\mathrm{Y}$ & 29.1 & 13.8 & 38.8 & 24.5 & 14.4 & 19.4 \\
\hline LREE & 178.68 & 73.06 & 158.51 & 179.7 & 219.3 & 108.5 \\
\hline HREE & 20.39 & 11.07 & 24.74 & 15.83 & 10.93 & 10.33 \\
\hline LREE/HREE & 8.76 & 6.60 & 6.41 & 11.35 & 20.07 & 10.50 \\
\hline$\sum$ REE & 199.07 & 84.13 & 183.25 & 195.6 & 230.3 & 118.8 \\
\hline$(\mathrm{La} / \mathrm{Yb})_{\mathrm{N}}$ & 10.23 & 4.85 & 6.25 & 35.08 & 63.42 & 46.07 \\
\hline $\mathrm{Eu} / \mathrm{Eu}^{*}$ & 0.56 & 0.85 & 0.28 & 0.82 & 0.74 & 0.47 \\
\hline $\mathrm{Ce} / \mathrm{Ce}^{*}$ & 0.97 & 0.97 & 0.97 & 1.02 & 1.05 & 0.99 \\
\hline
\end{tabular}

cating that the fractionation of light and heavy rare earth elements is weak. The Eu of the rock samples shows an evident negative anomaly, and the $\mathrm{Eu} / \mathrm{Eu}^{*}$ is between $0.47-0.82$.

Figure $9 \mathrm{~b}$ illustrates the primitive mantle standardized trace element spider diagram, where the Shirenshan gneiss and Taihua group migmatites are rich in $\mathrm{Cs}, \mathrm{Rb}, \mathrm{Th}, \mathrm{U}, \mathrm{La}$, and other large ion lithophile elements and high field strength elements $\mathrm{Nb}$, Ta, $\mathrm{Zr}$, and Hf. They are also very poor in $\mathrm{Sr}, \mathrm{P}, \mathrm{Ti}$, and other elements; which, is different from arc magmas. Compared to the Taihua Group migmatite, the Shirenshan gneiss is richer in $\mathrm{Th}, \mathrm{U}, \mathrm{Zr}$, and $\mathrm{Hf}$, and depleted in $\mathrm{Ba}, \mathrm{Ce}$, and $\mathrm{Y}$ where $\mathrm{P}$ and $\mathrm{Sr}$ are negative anomalies indicating the presence of plagioclase in the rock as a 

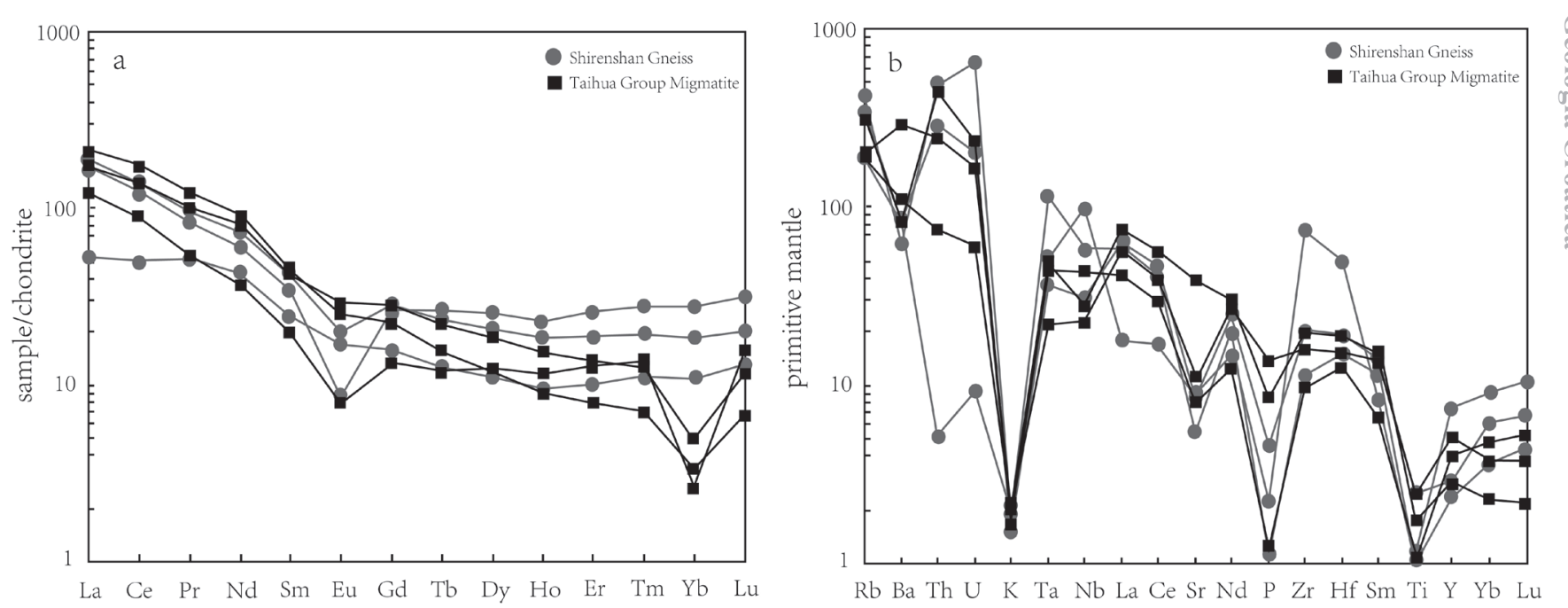

Figure 9. (a) Chondrite normalized REE patterns and (b) primitive mantle normalized trace element diagrams. (Normalization values after SUN et al., 1989).

molten residual phase or a crystalline separation phase. This supports a close relationship between the source rock material of the Shirenshan gneiss and the continental crust (SYLVESTER, 1998). The large losses of $\mathrm{P}$ and Ti indicate that the magma has undergone crystallization and separation of secondary minerals such as apatite and rutile (ROBERTS, 1993). In addition, the $\mathrm{Rb} / \mathrm{Sr}$ ratio of the Shirenshan gneiss and Taihua Group migmatite samples is higher than the $\mathrm{Rb} / \mathrm{Sr}$ ratio of the crust $(0.25)$, indicating that the source rock material may have an argillaceous crustal protolith (SISSON, 2005). In general, the Shirenshan gneiss and Taihua group migmatite samples show similar curve characteristics indicating that trace elements have similar geochemical behaviour and common source region properties.

\subsection{Sr-Nd isotope}

In this paper, six samples from the Shirenshan gneiss and Taihua Group migmatite were selected for $\mathrm{Sr}-\mathrm{Nd}$ isotope analysis (Table 3 ). There is no significant difference between the $\mathrm{Sr}-\mathrm{Nd}$ isotopic compositions of the Taihua Group migmatite and the Shirenshan gneiss samples. Among the Shirenshan gneiss samples, $\left({ }^{87} \mathrm{Sr} /{ }^{86} \mathrm{Sr}\right)_{\mathrm{i}}=0.71158-0.71763, \varepsilon_{\mathrm{Sr}}(\mathrm{t})=61.9-62.4,\left({ }^{143} \mathrm{Nd} /{ }^{144} \mathrm{Nd}\right)_{\mathrm{i}}=$ $0.511688-0.5122124, \varepsilon_{\mathrm{Nd}}(\mathrm{t})=-6.3-6.0$, among the Taihua group migmatite samples, $\left({ }^{87} \mathrm{Sr} /{ }^{86} \mathrm{Sr}\right)_{\mathrm{i}}=0.71193-0.71751, \varepsilon_{\mathrm{Sr}}(\mathrm{t})=61.8-62.2$, $\left({ }^{143} \mathrm{Nd} /{ }^{144} \mathrm{Nd}\right)_{\mathrm{i}}=0.5116956-0.5123385, \varepsilon_{\mathrm{Nd}}(\mathrm{t})=-5.9--5.5$.

\section{DISCUSSION}

\subsection{Geochronological significance}

In order to define the ages of multiple tectonic activity, LA-ICP$\mathrm{MS}$ zircon $\mathrm{U}-\mathrm{Pb}$ dating was performed on the Shirenshan gneiss and the weighted average age of ${ }^{206} \mathrm{~Pb} /{ }^{238} \mathrm{U}$ was obtained; $119.5 \pm 1.3 \mathrm{Ma}$ and $439.2 \pm 7.6 \mathrm{Ma}$. Some of the zircon cores are older and have a weighted average age of $1559 \pm 16 \mathrm{Ma}$ which represents the age of the intact rock without complete melting. It can be seen from the mineralogical characteristics and zircon age determinations (Table 1) that the zircon core of the Shirenshan gneiss was formed during the Mesoproterozoic. This is similar to the age of the Taihua Group (GAO et al., 2014) and indicates that the zircons of the Shirenshan gneiss originated from the ancient Taihua group. Zircon metamorphism is relatively low and the characteristics of magma crystallization are preserved. The age of 439.2 \pm 7.6 Ma in the mantle is the crystallization age of the magma after melting, which is consistent with the age of subduction of the Luoluan fault zone in the south of the Taihua Group gneiss (REN et al., 2016). This can be attributed to partial melting of the Taihua Group resulting from subduction and shearing of the Luoluan fault zone in the south of the Taihua Group. The age of the zircon rim of $119.5 \pm 1.3 \mathrm{Ma}$ corresponds to the intrusive age of the undeformed granite on the north side of the Shirenshan gneiss (WANG et al., 2017). In the Yanshanian period, due to regional migmatization, undeformed granite of Yanshanian age invaded the north side.

These results together with previous research data (REN et al., 2013) suggest that the Shirenshan gneiss protolith may have originated from the ancient geological bodies around the southern margin of the North China Block. Subduction of Luoluan fault zone from the south to the north in the late Caledonian particularly caused partial melting of the Taihua Group on the upper plate, and then invaded the weak zone caused by the left-lateral sliding leading to the formation of homotectonic magmatic rocks. The left-lateral sliding during the plastic phase resulted in the formation of the primary surface. After the crystallization of the magma, the left-lateral sliding activity continued and formed a mylonite strip in the gneiss. During the early Cretaceous period,

Table 3. Sr-Nd isotope data for the samples.

\begin{tabular}{|c|c|c|c|c|c|c|}
\hline Sample & NZ11 & NZ26 & NZ33 & NZ17 & NZ20 & NZ21 \\
\hline $87 \mathrm{Sr} / 86 \mathrm{Sr}$ & 0.711608 & 0.715894 & 0.717684 & 0.711963 & 0.715518 & 0.717557 \\
\hline$(87 \mathrm{Sr} / 86 \mathrm{Sr}) \mathrm{i}$ & 0.71158 & 0.71586 & 0.71763 & 0.71193 & 0.71555 & 0.71751 \\
\hline$\varepsilon S r(t)$ & 61.9 & 62.3 & 62.4 & 61.9 & 62.2 & 61.8 \\
\hline $143 \mathrm{Nd} / 144 \mathrm{Nd}$ & 0.511759 & 0.5117169 & 0.5122322 & 0.5120851 & 0.5123903 & 0.5117765 \\
\hline$(143 \mathrm{Nd} / 144 \mathrm{Nd}) \mathrm{i}$ & 0.511703 & 0.511688 & 0.5122124 & 0.512064 & 0.5123385 & 0.5116956 \\
\hline$\varepsilon N d(t)$ & -6.0 & -6.3 & -6.1 & -5.6 & -5.5 & -5.9 \\
\hline
\end{tabular}




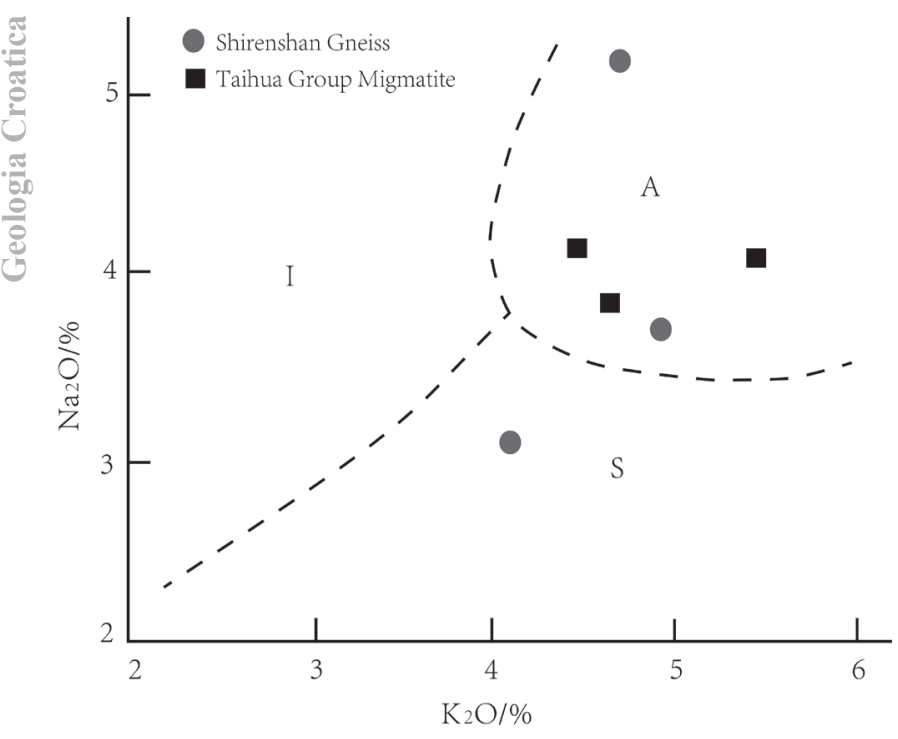

Figure 10. $\mathrm{Na}_{2} \mathrm{O}-\mathrm{K}_{2} \mathrm{O}$ diagram of the samples, legend $\mathrm{A}$, I, S type granite (COLLINS et al., 1982).

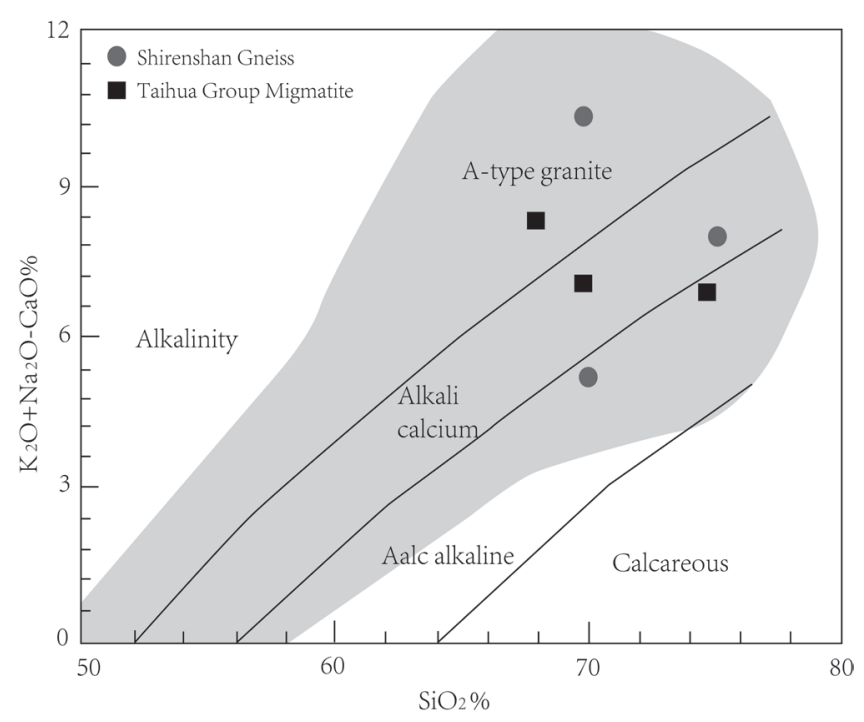

Figure 11. $\left(\mathrm{Na}_{2} \mathrm{O}+\mathrm{K}_{2} \mathrm{O}-\mathrm{CaO}\right)-\mathrm{SiO}_{2}$ diagram of the samples (FROST et al., 2001). due to regional migmatization, a large number of undeformed granites intruded into the northern part of the Shirenshan gneiss and experienced extensive thermal transformation.

\subsection{Precursor of the Shirenshan gneiss}

PITCHER (1982) classified granites into four types (I, S, M, and A) based on their differences in protolith and geochemical properties. This classification has been widely applied in the research on petrogenesis (COLTISS et al., 1982; WHALEN et Al., 1987; EBY, 1990). The M-type granite parental magma is derived from subducted oceanic crust or mantle wedge melting. After extensive fractional crystallization, a series of continuous gabbro and diorite rock combinations (PITCHER, 1982) were formed with geochemical properties of low $\mathrm{Rb}, \mathrm{Zr}, \mathrm{Nb}, \mathrm{Y}$, and REE content (WHALEN et al., 1987). Since A/CNK $<1$ and this characteristic is not consistent with the characteristics of the Shirenshan gneiss, the protolith is highly unlikely to be an M-type granite. The Stype granite source rocks are dominated by Al-rich sedimentary rocks. Al supersaturation and the minerals cordierite and muscovite often occur. Alternatively, S-type granites generally have lower oxygen fugacity, $\mathrm{Fe}^{3+} /\left(\mathrm{Fe}^{3+}+\mathrm{Fe}^{2+}\right)$ is about 0.153 (CHAPPELL, 1999). There is no aluminium-rich mineral production in the Shirenshan gneiss and the mean value of $\mathrm{Fe}^{3+} /\left(\mathrm{Fe}^{3+}+\mathrm{Fe}^{2+}\right)$ is 0.53 . This is obviously different from that of S-type granites. The sample shows a peraluminous feature, $\mathrm{A} / \mathrm{CNK}>1.1,{ }^{87} \mathrm{Sr} /{ }^{86} \mathrm{Sr}>0.705$, which is not inconsistent with the geochemical characteristics of type I granites. The Shirenshan gneiss has the characteristics of high silicon $\left(\mathrm{SiO}_{2}\right.$ content $\left.>67.64\right)$, alkali-rich $\left(\left(\mathrm{Na}_{2} \mathrm{O}+\mathrm{K}_{2} \mathrm{O}\right)\right.$ content $>7.14 \%$ ), calcium-poor $(\mathrm{CaO}$ content $<2.87 \%)$, and high $\mathrm{FeO}^{\mathrm{T}} / \mathrm{MgO}$ ratio $(>3.5)$. The sample data points in the $\mathrm{Na}_{2} \mathrm{O}-\mathrm{K}_{2} \mathrm{O}$ diagram (Fig. 10) fall into the A-type granite range. Furthermore, the rock is relatively rich in REE (except Eu) and the large ion lithophile elements ( $\mathrm{Cs}, \mathrm{Rb}, \mathrm{Th}, \mathrm{U}, \mathrm{La})$. However it is very poor in $\mathrm{Nb}$, Ti, and $\mathrm{Hf}$ and the other high field strength elements with a high $10000 \mathrm{Ga} / \mathrm{Al}$ ratio $>2.6$, (the lower limit of the A-type granite is 2.6). These features show that the Shirenshan gneiss originated from a A-type granite (Figs. 11 \& 12).

Type A granites are a product of post-collision or an intraplate environment. According to their geochemical characteristics, type A granites can be further divided into two subtypes, $\mathrm{A} 1$ and A2 (EBY, 1992). The A1 type granite generally represents
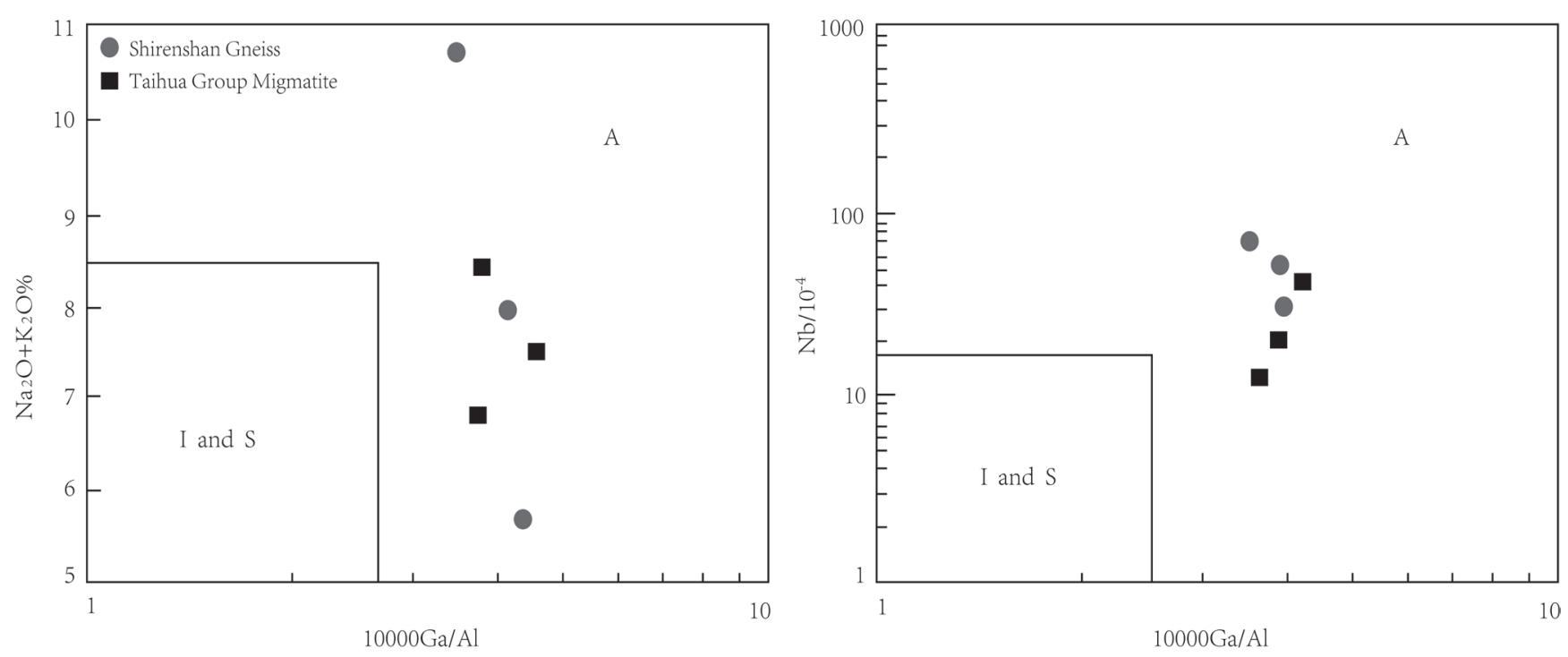

Figure 12. $\mathrm{Na}_{2} \mathrm{O}+\mathrm{K}_{2} \mathrm{O}$ and $\mathrm{Nb}-10000 \mathrm{Ga} / \mathrm{Al}$ diagram of the samples (WHALEN et al., 1987). 


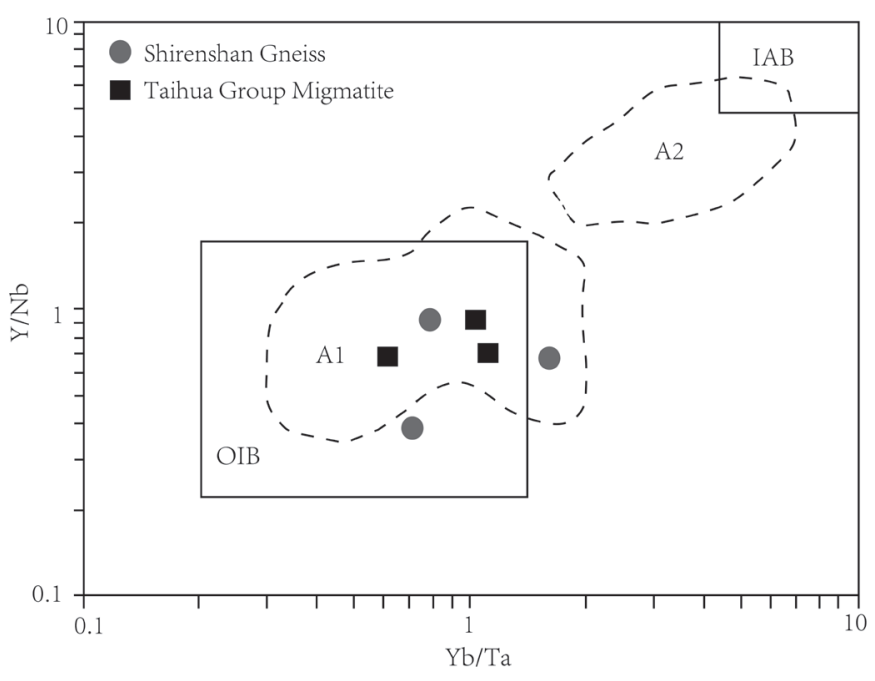

Figure 13. $\mathrm{Y} / \mathrm{Nb}-\mathrm{Yb} / \mathrm{Ta}$ and $\mathrm{Ce} / \mathrm{Nb}-\mathrm{Y} / \mathrm{Nb}$ diagrams (EBY, 1992).

a non-orogenic continental rift or intraplate environment. An A1 type granite source area is similar to the source area of the ocean island basalt (OIB) intruding into the continental rift under the non-orogenic system or the tectonic setting related to the mantle plume and hotspot. The source rock of the A2 type granite originates from the continental crust or crust formed during underplating in a continent-continent collision or island arc environment and its characteristic element ratio is between the island arc basalt (IAB) and the average continental crust (EBY, 1992). Since the ratio of $\mathrm{Y} / \mathrm{Nb}$ and $\mathrm{Yb} / \mathrm{Ta}$ is mainly controlled by the rock type in the source area, the crystallization differentiation of pyroxene, hornblende, and opaque minerals has a weak influence on the above ratio, the ratio of $\mathrm{Y} / \mathrm{Nb}$ and $\mathrm{Yb} / \mathrm{Ta}$ can be used to distinguish between the two types of A-type granites (EBY, 1992). In the $\mathrm{Y} / \mathrm{Nb}-\mathrm{Yb} / \mathrm{Ta}$ and $\mathrm{Ce} / \mathrm{Nb}-\mathrm{Y} / \mathrm{Nb}$ discriminant diagrams, the sample basically falls into the A1 type granite area (Fig. 13). It can be concluded here that the Shirenshan gneiss has a geochemical signature of an A1 type granite.

\subsection{Material source and genetic model}

The following genetic mechanisms were proposed in the literature for the formation of A-type granites: (1) partial melting of crustal materials at low pressure and high temperature (COLLINS et al., 1982; WHALEN et al., 1987; DOUCE, 1995); (2) direct derivation from the mantle source alkali basaltic magma (EBY, 1992; TURNER et al., 1992); and (3) a mixed product of the mantle source alkali basaltic magma and the magma formed under crust source anatexis (MINGRAM et al., 2000; BONIN, 2004).

Since the $\mathrm{Y}-\mathrm{Yb}$ incompatibility is stronger than the $\mathrm{Nb}$ and Ta, the magma formed by the partial melting of the lower crust or the upper crust has a higher $\mathrm{Yb} / \mathrm{Ta}$ and $\mathrm{Y} / \mathrm{Nb}$ ratio than the lower crust or the upper crust (RUDNICK et al., 2003). The ratio

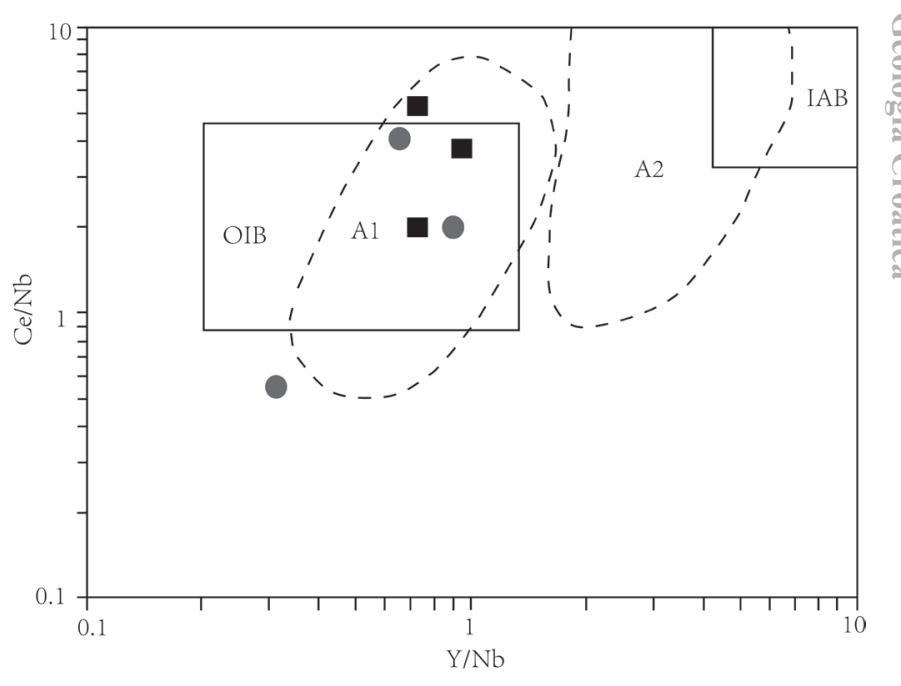

of the above elements in the Shirenshan gneiss is significantly lower than the ratio of the crust indicating that the genetic mechanism of partial melting of crustal material can be ruled out.

Previous studies have also shown that type A granite can be formed directly by fractional crystallization of mantle source basaltic magma (TURNER et al., 1992; DOUCE, 1995; KING et al., 1997). The intermediate-acid intrusive rocks with the same age as the Shirenshan gneiss such as the Taishanmiao granite and the Funiu Mountain granite, are common at the southern margin of the North China Block (REN et al., 2013). These rocks are often rich in $\mathrm{Rb}, \mathrm{Ba}$, and $\mathrm{Sr}$, large ion lithophile elements and high field strength elements such as $\mathrm{Nb}, \mathrm{Ta}, \mathrm{Zr}$, and $\mathrm{Hf}$, and relatively low in $\mathrm{Nd}$ isotopes, derived from the OIB melt formed by the asthenosphere metasomatized lithospheric mantle (WANG et al., 2019). The Shirenshan gneiss is enriched with light rare earth elements, large ion lithophile elements, and high field strength elements. This is consistent with the basalt formed from the asthenosphere metasomatized lithospheric mantle (TURNER et al., 1992). Hence, it is speculated that the Shirenshan gneiss may have a close genetic relationship with the mantle-derived magma at that time.

In general, crustal contamination can result in the loss of $\mathrm{Nb}$ and $\mathrm{Ta}$ in the magma, the enrichment of $\mathrm{Pb}$, and also affect the composition of the $\mathrm{Sr}, \mathrm{Nd}$, and Hf isotopes in the rock (RUDNICK et al., 2003). According to GAO et al. (2014), zircons in the gneiss in the Shirenshan area have a negative $\varepsilon \mathrm{Hf}(\mathrm{t})$ value (Table 4), a relatively discrete age distribution, and relatively enriched $\mathrm{Pb}$ elements. This shows that the magma has undergone a degree of crustal contamination during the upwelling process. However, there is no loss of $\mathrm{Nb}$ and $\mathrm{Ta}$ in the Shirenshan gneiss, which may be related to the relatively high concentration of high field strength elements and relatively weak crustal contamination in the rock source area.

Table 4. LA-MC-ICP-MS zircon Hf isotope data of the Shirenshan gneiss (according to GAO et al., 2014).

\begin{tabular}{|c|c|c|c|c|c|c|c|}
\hline Spot & ${ }^{176} \mathrm{Yb} /{ }^{177} \mathrm{Hf}$ & ${ }^{176} \mathrm{Lu} /{ }^{177} \mathrm{Hf}$ & ${ }^{176} \mathrm{Hf} /{ }^{177} \mathrm{Hf}$ & $\varepsilon_{\mathrm{Hf}}(\mathrm{t})$ & $\mathrm{T}_{\mathrm{DM} 1}(\mathrm{Ma})$ & TCDM & $\mathrm{f}_{\mathrm{Lu} / \mathrm{Hf}}$ \\
\hline No.1 & 0.013499 & 0.000608 & 0.281904 & -27.9 & 1877 & 2930 & -0.98 \\
\hline No.2 & 0.024122 & 0.001022 & 0.282429 & -9.4 & 1165 & 1777 & -0.97 \\
\hline No.4 & 0.030050 & 0.001279 & 0.282241 & -12.8 & 1309 & 1993 & -0.96 \\
\hline No.5 & 0.012840 & 0.000612 & 0.282394 & -15.9 & 1412 & 2190 & -0.98 \\
\hline
\end{tabular}


Based on the above analysis, it can be concluded that the Shirenshan gneiss was formed from the asthenosphere metasomatized lithospheric mantle during fractional crystallization. In addition, this set of OIB-like melts were affected by a degree of crustal contamination during the magma emplacement process.

\subsection{Geodynamic setting}

Type A granites have special petrogenetic significance and are only produced in a specific tectonic setting. The formation of A2 type granite is completed in a continent-continent collision environment or related to island arc magmatism; while the formation of A1 type granite occurs in a non-orogenic environment such as a continental fracture or inner plate related to an extension system (EBY, 1992). The Shirenshan gneiss in this study is an A1 type granite formed at $439 \mathrm{Ma}$. Its source area is similar to an oceanic island environment signature and is related to the Taihua Group migmatite. As shown in Fig.15, the sample points all fall into the area of granite at the plate. The previous studies concluded that this type of magmatic activity is often associated with mantle plume or asthenosphere mantle upwelling (EBY, 1992). The existing geological data indicates that the southern margin of the North China Block was outwith the non-supercontinent and an ancient oceanic basin developed at the margin (CAWOOD et al., 2013). In addition, there are no continental flood basalts in the North Qinling Block. It can be concluded here that the Shirenshan gneiss is highly unlikely to be associated with mantle plume activity.

The fracture zone of the subduction plate leads to back-arc extension and crustal thinning which can induce upwelling of the hot asthenospheric mantle forming a magma similar to OIB. For example: the eastern Alps (QORBANI et al., 2015), Mediterranean region (JOLOVET et al., 2015), and Central Mexico (FERRARI, 2004). Hence, we suggest that the Shirenshan gneiss was formed in the following dynamic setting: prior to formation of the Shirenshan gneiss, the southern margin of the North China Block was in a subduction-related island arc environment. The widely exposed Shirenshan gneiss is an A1 type granite and was formed in a back-arc extension environment. The geochemical characteristics of the Shirenshan gneiss are similar to the geochemical characteristics of the magmatic rocks formed in relation to the fracture zone of the subduction plate in both China and around the world. Both are rich in large ion lithophile elements $\mathrm{Rb}, \mathrm{K}, \mathrm{U}$, and $\mathrm{Pb}$ and high field strength (HFS) elements $\mathrm{Nb}, \mathrm{Ta}$, $\mathrm{Zr}$, and $\mathrm{Hf}$ from the asthenosphere metasomatized lithospheric mantle. Due to the similarity of the Sr-Nd isotope composition of the Shirenshan gneiss and the Taihua Group migmatite, the geochemical characteristics of the main trace elements are inherited. This indicates that the Taihua Group rock has the same material source as the gneiss in the middle of the Shirenshan area.

Based on the above regional geological data and previous research, the authors believe that at the southern margin of the North China Block, subduction and the strike-slip Luoluan fault zone resulted in crustal thinning, asthenosphere mantle upwelling, partial melting of the Taihua Group rocks, and the formation of a syntectonic magma during the Late Caledonian period. Beneath the subduction plate fault system, the intrusive fault zone along the tectonically weak zone facilitated the gneiss formation. During the early Cretaceous period, due to regional migmatization, a large number of undeformed granites intruded the north side resulting in the Yanshanian age. Hence, the metamorphic deformation of the Shirenshan gneiss is a reflection of the tectonic-magmatic activity in the Shirenshan area on the southern margin of the North China Block. This is of great significance for further studies on the plate edge deformation during the subduction process.

\section{CONCLUSIONS}

Through a detailed study of structural geology, petrology, geochemistry, chronology, and tectonic environment of the Shirenshan gneiss, the following conclusions can be drawn:

(1) The protolith age of the Shirenshan gneiss is $1559 \pm 16 \mathrm{Ma}$ (early Mesoproterozoic). Then, it was melted under the impact of the subduction of the plate and formed an isostructure magmatite with a crystallization age of $439.2 \pm 7.6 \mathrm{Ma}$ (Late Caledonian). At $119.5 \pm 1.3 \mathrm{Ma}$, the early Cretaceous, the Shirenshan gneiss may have undergone regional migmatization which results in the age of the Yanshanian.

(2) The Shirenshan gneiss is mainly composed of biotite plagiogneiss and felsic gneiss characterized by its high $\mathrm{SiO}_{2}, \mathrm{Al}_{2} \mathrm{O}_{3}$, $\mathrm{K}_{2} \mathrm{O}, \mathrm{Na}_{2} \mathrm{O}$, and low $\mathrm{CaO}, \mathrm{MgO}$. It is a strong peraluminous high$\mathrm{K}$ calc-alkaline $\mathrm{A} 1$ granite formed in an oceanic island environment molded by the asthenosphere metasomatized lithospheric mantle under fractional crystallization with a degree of crustal contamination.

(3) There is no significant difference in the main trace elements and Sr-Nd isotopic compositions of the samples. This indicates that the Taihua Group migmatite and the Shirenshan gneiss have the same material source, namely the Shirenshan
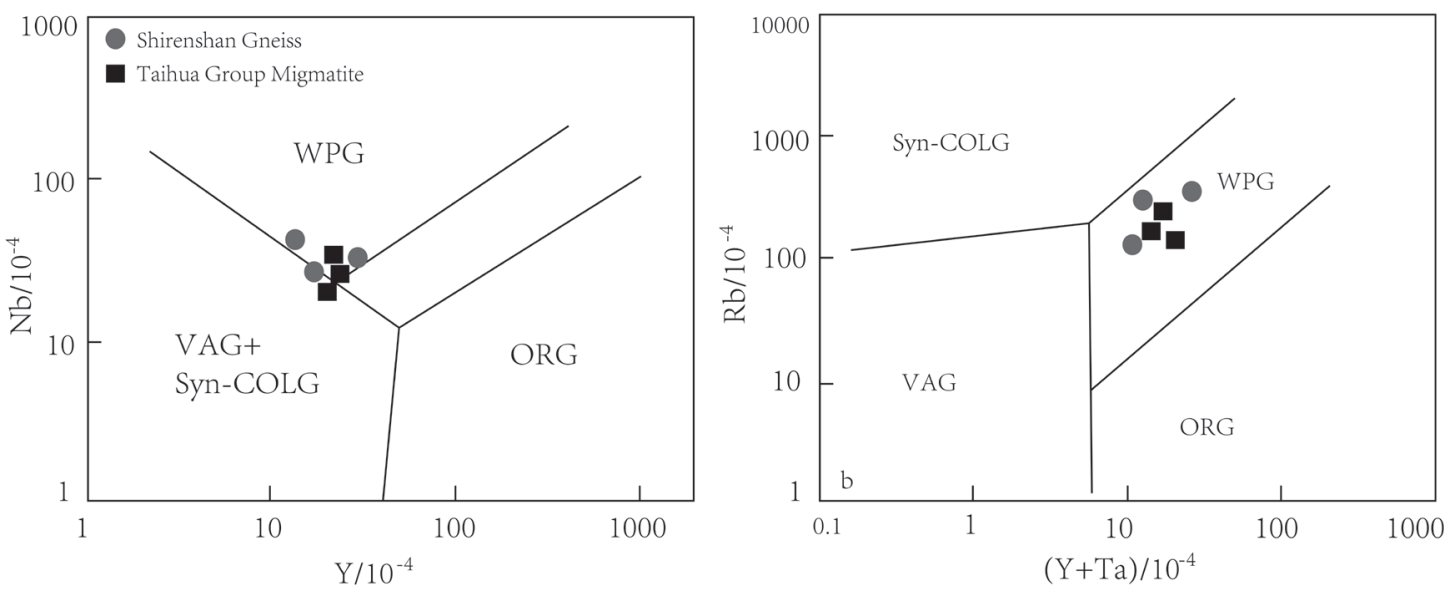

Figure 14. A granitic gneiss tectonic discrimination map. Legend: volcanic arc granite (VAG), syn-tectonic collision granite (Syn-COLG), within plate granite (WPG) and ocean ridge granite (ORG) (PEARCE et al., 1984). 
block. Gneiss may be formed due to partial melting of the Taihua Group and deformation of the Luoluan fault zone.

(4) Combining regional tectonic evolution characteristics and geochemical characteristics of the Shirenshan gneiss, the authors believe that the Shirenshan gneiss in the southern margin of the North China Block has the structural properties of an intraplate granite. This suggests that during the Late Caledonian period, the southern margin of the North China Block was in a back-arc extension environment caused by the rupture of the subducting slab.

\section{ACKNOWLEDGEMENT}

This study was supported by the National Nature Science Foundation of China (Nos. 41572177, 41272213, 41573023, 41072161, $41502193,41272222)$. The authors wish to express their gratitude to the reviewers for their thoughtful suggestions and comments. Thanks are also due to all who have contributed to the execution of this research.

\section{REFERENCES}

BONIN, B. (2004). Do coeval mafic and felsic magmas in postcollisional to within-Plate regimes necessarily imply two contrasting, mantle and crustal, sources? A review.Lithos, 78/1, 1-24. doi: 10.1016/j.lithos.2004.04.042

CAWOOD, P. A., WANG, Y. J. \& XU, Y. J. (2013): Locating South China in Rodina and Gondwana: A Fragment of Greater India Lithosphere? - Geology, 41/8, 903-906. doi: 10.1130/G34395.1

CHAPPELL, B. (1999): Aluminium saturation in I and S-type granites and the characterization of fractionated haplogranites.- Lithos, 46/3, 535-551. doi: 10.1016/S00244937(98)00086-3

COLLINS, W.J. (1982): Nature and origin of A type granites with particular reference to Southeastern Australian.- Contributions to Mineralogy and Petrology, 80/6, 189-200.

DONG, Y.P., ZHANG, G.W. \& ZHAO, X. (2003): The proterozoic tectonic framework and evolution of the north Qinling orogen, central China. (in Chinese, with an English Abstract).- Geotectonica et Metallogenia, 27/2, 115-124.

DOUCE, A.E.P. \& BEARD, J.S. (1995): Dehydration-melting of biotite gneiss and quartz amphibolite from 3 to 15 kbar.- Journal of Petrology, 36/3, 707-738. doi: 10.1093/ petrology/36.3.707

EBY, G.N. (1990): The A-type granitoids: A review of their occurrence and chemical characteristics and speculations on their petrogenesis.- Lithos, 26/1-2, 115-134. doi: 10.1016/0024-4937(90)90043-Z

EBY, G.N. (1992): Chemical subdivision of the A-type granitoids: Petrogenetic and tectonic implication.- Geology, 20/7, 641-644. doi: 10.1130/0091-7613(1992)020< 0641:CSOTAT>2.3.CO;2

FERRAR, L. (2004): Slab detachment control on mafic volcanic pulse and mantle heterogeneity in Central Mexico.- Geology, 32/1, 77. doi: 10.1130/G19887.1

FROST, B.R., BARNES, C.G., COLLINS, W.J., ARCULUS, R.J., ELLIS, D.J. \& FROST, C.D. (2001): A geochemical classification for granitic rocks.- Journal of Petrology, 42/11, 2033-2048. doi: 10.1093/petrology/42.11.2033

GAO, X.Y., ZHAO, T.P. \& CHEN, W.T. (2014): Petrogenesis of the early Cretaceous Funiushan granites on the southern margin of the North China Craton: Implications for the Mesozoic geological evolution.- Journal of Asian Earth Sciences, 94/2014, 28-44. doi: 10.1016/j.jseaes.2014.07.042

JOLIVET, L., MENANT, A. \& STERNAI, P. (2015): The geological signature of a slab tear below the Aegean.- Tectonophysics, 659, 166-182. doi: 10.1016/j.tecto.2015. 08.004

KING, P.L., WHITE, A.J.R. \& CHAPPELL, B. W. (1997): Characterization and origin of Aluminous A-Type Granites from the Lachlan Fold Belt, Southeastern Australia.Journal of Petrology, 38/3, 371-391. doi: 10.1093/petroj/38.3.371

LIU, Y.S., GAO, S., YUAN, H.L., ZHOU, L., LIU, X.M., WANG, X.C., HI, Z.C. \& WANG, L.S. (2004): U/Pb zircon ages and $\mathrm{Nd}$, $\mathrm{Sr}$ and $\mathrm{Pb}$ isotopes of lower crustal xenoliths from North China Craton: Insights on evolution of lower continental crust.Chemical Geology, 211/1-2, 87-109. doi: 10.1016/j.chemgeo.2004.06.023

LIU, Y.S., HU, Z.C., ZONG, K.Q., CAO, C.G., CAO, S., XU, J. \& CHEN, H.H. (2010): Reappraisement and refinement of zircon $\mathrm{U}-\mathrm{Pb}$ isotope and trace element analyses by LA-ICP-MS. (in Chinese, with an English Abstract).- Chinese Science Bulletin, $55 / 15,1535-1546$.

LU, S.W. (1995): Geological characteristics of granite in Funiushan region and its genesis. (in Chinese, with an English Abstract).- Henan Geology, 13/3, 183-190.

MANIAR, P.D. \& PICCOLOLI, P.M. (1989): Tectonic discrimination of granitoids.-- Geological Society of America Bulletin, 101/5, 635-643. doi: 10.1130/0016-7606(1989) 101\%3C0635:TDOG\%3E2.3.CO;2

MINGRAM, B., TRUMBULL, R. B. \& LITTMAN, S. (2000): A petrogenetic study of anorogenic felsic magmatism in the Cretaceous paresis ring complex, Namibia: Ev- idence for mixing of crust and mantle-derived components.- Lithos, 54/1, 1-22. doi: 10.1016/S0024-4937(00)00033-5

PEARCE, J.A., HARRIS, N.B.W. \& TINDLE, A.G. (1984): Trace element distrimination diagrams for the tectonic interpretation of granitic rocks.- Journal of Petrology, 25/4, 956-983.

PECCERILLO, A. \& TAYLOR, S.R. (1976): Geochemistry of Eocene calc-alkaline rocks from Kastamonu area - Northern Turkey.- Contributions to Mineralogy and Petrology, 58, 63-81.

PEI, X.Z., ZHANG, W.J. \& WANG, T. (1995): Geological features and tectonic evolution of the North Qinling Mountains orogenic belt. (in Chinese, with an English Abstract).- Northwestern Geology, 16/4, 8-12.

PITCHER, W.S. (1982): Granite type and tectonic environment.- Mountain Building Processes.-Academic Press, London, 19-40.

QORBANI, E., BIANCHI, I. \& BOKELMANN, G. (2015): Slab detachment under the eastern alps seen by seismic anisotropy.- Earth and Planetary Science Letters, 409, 96-108. doi: 10.1016/j.eps1.2014.10.049

REN, S.L. (2013): Metamorphic deformation analysis of the Funiushan tectonic belt, Qinling.- Hefei University of Technology Press.

REN, S.L, LIU, G.T. \& SONG, C.Z. (2016): Deformation and metamorphic characteristics of amphiboles in the Luonan-Luanchuan fault belt of the Qinling Orogen and its significance. (in Chinese, with an English Abstract).- Acta Petrologica Sinica, 32/3, 775-786.

ROBERTS, M.P. \& CLEMENS, J.D. (1993): Origin of high-potassium, talc-alkaline, Itype granitoids.- Geology, 21, 825-828. doi: 10.1130/0091-7613(1993)021\%3C08 25:OOHPTA\%3E2.3.CO;2

RUDNICK, R.L. \& GAO, S. (2003): Composition of the continental crust. In: Rudnick R. L. ed., Treatise on Geochemistry 3.- Elsevier, Amsterdam, 1-46. doi: 10.1016/B008-043751-6/03016-4

SISSON, T., RATAJESKI, K., HANKINS, W. \& GLAZNER, A. (2005): Voluminous granitic magmas from common basaltic sources.-Contrib. Miner. Petrol., 148, 635-661. doi: 10.1007/s00410-004-0632-9

SONG, C.Z., LIU, G.S. \& NIU, M.L. (2002): Genozoic structures and dynamics on the northern margin of the Qinling-Dabie orogenic belt. (in Chinese, with an English Abstract).- Geological Bulletin of China, 21/9, 530-535.

SONG, C.Z., ZHANG, G.W. \& NIU, M.L. (2006): Oblique collision and convergence factor on the northern margin of the Qinling orogenic belt. (in Chinese, with an English Abstract).- Geology in China, 33/1, 48-55.

SUN, S.S. \& MCDONOUGH, W.F. (1989). Chemical isotopic systematics of oceanic basalts: Implications for mantle composition and processes.- Magmatism in the Ocean Basins.- Geological Society of London Special Publication, 42/1, 313-345. doi: 10.1144/GSL.SP.1989.042.01.19

SYLVESTER, P.J. (1998): Post-collisional strongly peraluminous granites.- Lithos, 45, 29-44. doi: 10.1016/S0024-4937(98)00024-3

TURNER, S., SANDIFORD, M. \& FODEN, J. (1992): Some geodynamic and compositional constraints on "Postorogenic" magmatism.- Geology, 20/10, 931.

WANG, J.G. \& LU, X.X. (1988): The petrological features of Funiushan granite. (in Chinese, with an English Abstract).- Geology of Henan, 6/3, 35-40.

WANG, J.Y., REN, S.L. \& LI, J.H. (2017): Study on Deformation of Shirenshan Block in the North Qinling.-Acta Geologica Sinica - English Edition, 91/1, 351-352.

WANG, J.Y., REN, S. L., JIANG, D. Z., DONG, S. W., LI, J. H., LI, L. M., SONG, C. Z., HAN, H. \& LI, Z. Q. (2019): New Zircon U-Pb Ages of the Shirenshan Gneiss, North Qinling and Their Geological Implications.- Acta Geologica Sinica - English Edition, 93/1, 238-240. doi: 10.1111/1755-6724.13792

WHALEN, J.B., CURRIE, K.L. \& CHAPPELL, B.W. (1987): A-type granites: geochemical characteristics, discrimination and petrogenesis.- Contributions to Mineralogy and Petrology, 95/4, 407-419. doi: 10.1007/BF00402202

WU, A.M., MARTARELLI, L., MA, R., WANG, H., YANG, H.F. \& BU, H. (2018): Common and different features of Chinese and Italian hydrogeological mapping guidelines.- Geologia Croatica, 71/2, 105-111. doi: 10.4154/gc.2018.07

XU, Z.Q., LI, Y. \& LIANG, F.H. (2015): A connection between of the Paleo-Tethys suture zone in the the Taihua group on the southern margin of the North China craton: further insights from $\mathrm{U}-\mathrm{Pb}$ ages and $\mathrm{Hf}$ isotope compositions of zircons.- Mineral. Petrol., 97, 43-59.

XU, Z.Q., LI, Y.L. \& TANG, Y.Q. (1990): The formation of the Qinling Mountain China as the backbone of China, convergence, collision and intracontinental subduction in Chinese, with an English Abstract.- Bulletin of the Chinese Academy of Geological Sciences, 20/1, 130-132.

ZHANG, G.W., DONG, Y.P. \& YAO, A.P. (1997): The crustal compositions,structures and tectonic evolution of the Qinling orogenic belt - in Chinese, with an English Abstract.- Geology of Shanxi, 15/2, 1-14.

ZHANG, Z.W. \& LI, S.M. (1998): Sm-Nd and Rb-Sr ages of the Archean Taihua Group metamorphic rocks in the Xiong'ershan region, Western Henan province.- In: CHENG, Y.Q. (Ed.: Precambrian Geological Research Papers of the North China Platform. Geological Publishing House, Beijing, 123-132.

ZHANG, G.W., ZHANG, B.R., YUAN, X.C. \& XIAO, Q.H. (2001). Qinling Orogenic Belt and Continental Dynamics (in Chinese, with an English Abstract).- Sci. Press, Beijing, 1-806. 